\title{
Invited review: Abomasal emptying in calves and its potential influence on gastrointestinal disease
}

\author{
Johann Burgstaller, ${ }^{*}$ Thomas Wittek, ${ }^{*}$ and Geof W. Smith ${ }^{1}$ \\ *University Clinic for Ruminants, Veterinary University Vienna, 1210 Vienna, Austria \\ †Department of Population Health and Pathobiology, College of Veterinary Medicine, North Carolina State University, Raleigh 27607
}

\begin{abstract}
Creating the ideal nutrition program for calves is a demanding task that has undergone tremendous change in recent years. Products and technologies including novel milk replacers and automated calf feeding systems have been developed to facilitate the ability of dairy producers to feed for higher growth rates before weaning. The creation of new feeding programs and milk replacers has to be looked at carefully, not only from a nutrition point of view but also from the perspective of a potential effect on physiologic digestion and calf health. Abomasal emptying is a critical factor that may link nutrition and disease. The purpose of this article is to review both intrinsic and extrinsic factors that are responsible for abomasal emptying. Predominant extrinsic factors controlling abomasal emptying include meal volume, energy density, and osmolality along with the content and source of protein. This article also reviews experimental methods used to measure abomasal emptying in the calf including those that would be appropriate for use under field conditions. Among these methods, the use of ultrasonography and different absorption tests (D-xylose, acetaminophen) as tools to measure abomasal emptying are discussed. The relationship between abomasal emptying and disease is explored, particularly as it relates to abomasal bloat. Abomasal bloat is a complex syndrome that seems to be increasing in frequency and whose etiology likely at least partially involves slowing of abomasal emptying. Suggestions for minimizing the effect of feeding programs on abomasal emptying are explored as well as needs for future research.
\end{abstract}

Key words: abomasum, bloat, tympany, milk replacer, osmolality

Received January 26, 2016.

Accepted September 22, 2016.

${ }^{1}$ Corresponding author: Geoffrey_Smith@ncsu.edu

\section{INTRODUCTION}

Research on nutrition and feeding of the dairy calf has gone through a renaissance in recent years. Conventional programs designed to limit feed calves at approximately 8 to $10 \%$ of their BW per day have been popular for decades. These programs were designed to limit the cost spent on milk or milk replacer diets and encourage early solid feed intake so calves could be quickly weaned onto less expensive feeds (Kertz and Loften, 2013). More recently, significant interest has arisen for increasing volumes of liquid feed offered to calves, offering milk more frequently, and increasing the nutrient content (protein, fat, or both) of milk replacers (Khan et al., 2011). Increasing the level of nutrition provided to dairy calves in the first weeks of life has resulted in several benefits such as decreased morbidity and mortality (Godden et al., 2005), faster recovery from disease (Ollivett et al., 2012), decreased age at first calving (Radcliff et al., 2000; Davis Rincker et al., 2011), improved mammary development (Lohakare et al., 2012), and increased milk production as an adult (Soberon et al., 2012; Soberon and Van Amburgh, 2013). Products and technologies including novel milk replacers, automated calf feeding systems, and the acidification of milk have all been introduced largely to assist dairy producers who wish to feed for more preweaning growth.

Some of these improvements in dairy calf feeding have the potential to alter abomasal emptying rates in calves. Abomasal emptying refers to the time span the chymus remains in the abomasum before passing into the intestinal tract, which is a concept similar to gastric emptying in humans. Feeding practices that significantly prolong abomasal emptying could increase rates of gastrointestinal diseases in calves such as abomasal bloat (Glenn Songer and Miskimins, 2005). The condition gastroparesis or delayed gastric emptying is well described in humans and is associated with multiple abnormalities including gastroesophageal reflux, abdominal pain, vomiting, bloating, or poor 
appetite (Pasricha and Parkman, 2015). Differences between feeding of dairy calves as compared with a beef calf suckling milk from the dam can be seen in milk volume per feeding, frequency of intake, $\mathrm{pH}$, curd formation, content and origin of fat and protein, as well as the electrolytes and osmolality of the milk replacers. The intake of certain milk replacers, which may show substantially different chemical and physical characteristics compared with whole milk, may lead to digestive problems for the calf (Constable et al., 2006; Marshall, 2009). The purpose of this article is to review the factors that influence abomasal emptying and the research methods for determining abomasal emptying. Furthermore, possible relationships between abomasal emptying and gastrointestinal disease in calves will be discussed.

\section{PRIMARY FACTORS CONTROLLING ABOMASAL EMPTYING IN CALVES}

Abomasal emptying rate is potentially influenced by several factors (Table 1) such as volume and osmolality of the ingested meal, motility, luminal pressure and abomasal wall contractions, viscosity of ingesta, antroduodenal coordination, and resistance of the pylorus (Thomas et al., 1934; Thomas, 1957; Schulze-Delrieu and Brown, 1985). Even though the forestomachs in ruminants are different from those of monogastric animals from an anatomic point of view, similar mechanisms for gastric emptying have been described (Low, 1990; Cottrell and Stanley, 1992; Malbert and Mathis, 1994). Abomasal emptying occurs if the abomasal body (corpus abomasi) transports ingesta to pyloric antrum (antrum pyloricum), which is then responsible for further transport of the ingesta into the duodenum by coordinated contraction while the pylorus is opened. The beginning of the duodenum incorporates and transports ingesta further down the intestinal tract (Ruckebusch and Pairet, 1984; Malbert and Ruckebusch, 1988, 1991). Motility and emptying of the abomasum are under both neural and humoral control.

\section{Neural Control of Abomasal Motility and Emptying}

Extrinsic Innervation. Abomasal motility is predominantly controlled by the ventral branch of the abdominal vagal nerve. Although the dorsal branch primarily innervates the rumen, some parts are also involved in innervation of the abomasum (Habel, 1956). The parasympathetic fibers innervate neurons that increase motility and relax abomasal tone. Therefore, afferent and efferent vagal pathways (vagal reflex) are responsible for accommodation and relaxation of the abomasum while the animal is eating (Jahnberg et al., 1977; Cottrell, 1994; Olson and Holmgreen, 2001). Anatomic position, branching, and anastomosis of the vagal nerve vary significantly from animal to animal, which explains different clinical outcomes from similar damage done to branches of the nerve (Hoflund, 1940; Dietz et al., 1970; Baker, 1979). Vagal nerve damage might result from infectious processes originating from the esophagus, thrombophlebitis of the jugular vein, mediastinitis, or peritonitis. This nerve damage might result in no clinical signs at all, or it could cause a chronic decrease in abomasal emptying, resulting in obstruction of the abomasum (vagal indigestion or Hoflund's syndrome). Changes in the electrical activity of the abomasum were reported after vagotomy (Gregory et al., 1984). The effect of vagotomy on abomasal emptying in calves has been reported by Bell et al. (1977) using radiology to document slower transport of milk containing a contrast agent.

Intrinsic Innervation. Intrinsic innervation is present in the wall of the abomasum. This localization is similar to that of monogastric animals, but ruminants otherwise have substantial differences (Pfannkuche et al., 2002). Cholinergic, muscarinic, and nicotinic parts of the intramural nervous system in the abomasum and small intestine are responsible for generation and control of electrical procedures, called minute rhythm (Kuiper and Breukink, 1988; Romański, 2002). Receptors in the wall are able to detect tension and therefore filling of the organ. Increased tension of the wall leads to increased motility of the pyloric antrum, which is affected

Table 1. Factors increasing and decreasing abomasal emptying

\begin{tabular}{ll}
\hline Accelerates abomasal emptying & Decreases or slows abomasal emptying \\
\hline Wheat-, fish-, or soy protein-based milk & Large volume \\
replacer & Fed with esophageal intubation or feeder \\
& High caloric content \\
& High osmolality \\
& High intra-abomasal pressure \\
& pH lower than 2 or higher than 10 \\
& High glucose-containing oral electrolyte solutions \\
\hline
\end{tabular}


by the vagal reflex, as mentioned earlier, along with reflex pathways of the intrinsic neural system (Cottrell and Stanley, 1992). Receptor density and location varies between different organs of the gastrointestinal tract, and mRNA coding for adrenergic receptors is present in different concentrations and subtypes between animals (Meylan et al., 2004a).

\section{Humoral Control of Abomasal Emptying and Motility}

Numerous mediators and hormones (motilin, pancreatic polypeptide, secretin, cholecystokinin, somatostatin, gastrin, vasoactive intestinal peptide, peptide YY, vasopressin, oxytocin, glucagon-like-peptide 1, interleukin 1 $\beta$ ) may influence abomasal motility and emptying rate as well as affect and regulate the function of the gastrointestinal tract (Bell et al., 1981a). These mediators and hormones affect motility and secretion, which are regulated by feedback mechanisms and feedstuff properties (Yasuda et al., 1988; Zabielski et al., 1998). Secretin (1 U/kg per hour) und cholecystokinin (0.5 to $4 \mathrm{U} / \mathrm{kg}$ per hour) have been shown to affect the electronic potentials in the abomasal wall, which results in a decrease or absence of electrical potentials and therefore produces slow or incomplete abomasal emptying (McLeay and Bell, 1980). Nitric oxide is a major local mediator that affects abomasal motility and emptying (Adams, 1996; Sun et al., 1998). Serotonin affects the motility of the entire gastrointestinal tract because it activates both intrinsic and extrinsic primary afferent neurons to initiate peristaltic and secretory reflexes and to transmit this information to the central nervous system (Spring et al., 2003; Meylan et al., 2004b). Insulin also affects abomasal emptying (van Meirhaeghe et al., 1988), and hyperglycemic animals with increased endogenous insulin secretion or animals that have been given exogenous insulin injections show decreased abomasal emptying rates of up to $50 \%$ for a few hours. The in vitro effect of prostaglandins as local mediators on abomasal motility was studied intensively using muscle baths, which showed effects on muscle from both the abomasal body and pylorus (Vandeplassche et al., 1982a,b, 1984). In vivo experiments demonstrated changes in intraluminal pressure after intramuscular injection of $\mathrm{PGE}_{1}$ and $\mathrm{PGE}_{2}$ (both $2.5 \mathrm{mg}$ ); however, no changes in the electromyographic recordings occurred and only small but nonsignificant effects on abomasal emptying were observed. Infusion of $40 \mathrm{mg}$ of $\mathrm{PGF} 2_{\alpha}$ for a 1 -h period did not affect intraluminal pressure, electric potential, or emptying rate Vlaminck et al. (1984). In summary, abomasal emptying is under complex hormonal influence in calves; however, more research is needed to further define the role that the various individual peptides play in the process. Fur- thermore, a substantial gap exists in our knowledge of how the humoral control specifically affects abomasal emptying in calves of different ages because most of the work to date has been done either in adult ruminants or in vitro.

\section{Effect of Ingesta and Milk Clot Formation on Abomasal Motility and Emptying}

The passage of ingesta through the gastrointestinal tract of ruminants is predominantly affected by the physical and chemical characteristics of the feed, although climate, hormonal, environmental, and individual factors regulate feed intake and passage rate (Okine et al., 1998). The composition of the feedstuff induces the endocrine release of peptides in calves, which affects gastrointestinal function (Zabielski et al., 1998).

The formation of a milk clot in the abomasum has the potential to affect abomasal emptying in calves; however, little research has been done to directly examine this effect. Milk replacers that do not clot in the abomasum have been hypothesized to be emptied significantly faster than whole milk or milk replacers that do clot (le Huërou-Luron et al., 1998). However, in one study calves fed whole milk had faster abomasal emptying than calves fed either an all milk protein or combination milk and soy protein milk replacer when fed twice daily at $12 \%$ of BW (Constable et al., 2005). The authors confirmed that the whole milk clotted in the abomasum while both milk replacers failed to clot after feeding. It should be noted though that the osmolalities of both milk replacers were higher $(375 \mathrm{mOsm} / \mathrm{L}$ for milk protein and $410 \mathrm{mOsm} / \mathrm{L}$ for the milk-soy product) than that of whole milk $(278 \mathrm{mOsm} / \mathrm{L})$, and this higher osmolality could also delay abomasal emptying. Overall, more research examining the importance of milk clot formation on abomasal emptying is needed.

\section{Volume of Ingested Meal}

The volume of milk or feed ingested is an important factor that controls abomasal emptying rate in both monogastric and ruminant species (Bell and Razig, 1973). In data from 3 different studies, dairy calves fed 2 L of a milk protein-based milk replacer with $20 \%$ fat and $20 \%$ protein had an average abomasal emptying time between 190 and 206 min measured by means of maximum acetaminophen concentration (Sen et al., 2006; Nouri and Constable, 2007; Marshall et al., 2008). In comparison, abomasal emptying following $2 \mathrm{~L}$ of whole milk ingestion takes 129 to $191 \mathrm{~min}$ (Nouri et al., 2008; Afshari et al., 2009; Constable et al., 2009). In mature cattle, the capacity of the abomasum is relatively constant and small because of 
the continuous in- and outflow of ingesta (Hunt and Stubbs, 1975; Low, 1990; Constable et al., 2005). Model studies performed in sheep and goats showed strong associations between abomasal volume and emptying and feed intake (Ehrlein and Hill, 1970; Wegrzyn, 1981; Gregory et al., 1985). The capacity of the abomasum is relatively constant in adult ruminants, but not in calves. In calves, the capacity of the abomasum enlarges significantly after ingestion of a liquid meal. In calves 7 to $30 \mathrm{~d}$ of age, the mean preprandial abomasal volume was $62 \mathrm{~mL}$ (range $20-137 \mathrm{~mL}$ ) as measured by ultrasonography (Wittek et al., 2005a). Mean abomasal volume was calculated as $897 \mathrm{~mL}$ following the ingestion of $1 \mathrm{~L}$ of milk, $1,711 \mathrm{~mL}$ after ingesting $2 \mathrm{~L}$, and $2,956 \mathrm{~mL}$ after ingesting $3 \mathrm{~L}$. Thus the abomasum of the young calf is similar to the stomach of monogastric animals in that capacity increases significantly with meal size (Wittek et al., 2005a) This increase is of critical importance in calves in that volume of milk ingested can vary substantially between farms because of different feeding protocols and frequency. Historically, most feeding programs have provided 4 to $5 \mathrm{~L}$ of liquid feed per day split into equal volumes and fed twice a day. However, more liberal feeding programs advocate feeding much larger volumes of milk at one time. In addition, some studies have advocated feeding calves a large volume of milk (4-6 L) once a day as a way to save labor (Hopkins, 1997). Research has shown that calves offered milk ad libitum vary significantly in the number of feedings per day and in the volume of milk ingested at each feeding (Appleby et al., 2001). However most calves will attempt to suckle at least 3 times per day, and sometimes as many as 8 to 10 times per day (Appleby et al., 2001; Miller-Cushon et al., 2013). To some degree, calves are able to compensate for limited feeding time by consuming larger intakes at each meal (von Keyserlingk et al., 2006). However, the greater the volume of milk offered to a calf during each feeding, the longer that milk will remain in the abomasum. Therefore, feeding programs that favor smaller volumes of milk offered more frequently may have some benefit. In addition, social interaction has an important role on feed intake, behavior, and performance of dairy calves (Khan et al., 2011; Jensen et al., 2015). In summary, future studies investigating the effect of milk feeding volume on gastrointestinal health are indicated, and larger volumes of milk per feeding have the potential to slow abomasal emptying.

\section{Feeding Method}

Although not specifically related to volume, calves fed milk or electrolytes with an esophageal feeder will also have slower abomasal emptying as compared with bottle feeding because the liquid first enters the rumen and then enters the abomasum. In one study the same oral electrolyte solution (OES) was administered to calves both by esophageal intubation and suckling (Nouri and Constable, 2006). As would be expected, the calves fed by esophageal intubation had slower emptying rates. Many producers have noted that continual feeding of calves using esophageal feeders may result in bloat or fluid pooling in the forestomachs, likely related to the delay in emptying time. Older studies comparing open pail (bucket) and nipple feeding found little difference in general parameters such as health status of the calves or weight gain. However, although closure of the esophageal groove was not different between methods, larger volumes of milk appeared earlier in the intestines after bucket feeding in comparison to nipple feeding. This finding indicated an effect of the feeding method on passage rate through the abomasum (Wise and Lamaster, 1968; Abe et al., 1979).

\section{Energy Density and Osmolality of Ingested Meal}

Next to volume, the caloric density of an ingested fluid meal is likely the most important determinant of abomasal emptying rate (Hunt and Stubbs, 1975). Energy density, which is determined among other factors by different proportions of lactose and fat, is most often proportional to osmolality, which is measured by osmoreceptors in the duodenum (Bell and McLeay, 1978). Low caloric isotonic fluids, such as isotonic $\mathrm{NaHCO}_{3}$, are emptied from the abomasum rapidly (Sen et al., 2006), while higher caloric fluids, such as isotonic glucose solution or some milk replacers, are absorbed in a more linear manner to ensure ingesta are constantly presented to the small intestine. Hypertonic solutions (>300 mOsm/L) decrease emptying rate in calves as compared with isotonic electrolyte solutions, with very hypertonic $(\geq 600 \mathrm{mOsm} / \mathrm{L})$ solutions substantially slowing emptying (Bell and Razig, 1973; Sen et al., 2006). This effect is present independent of caloric density. Bell and Webber (1979) reported that abomasal emptying of isocaloric hypo-osmolar $(<300 \mathrm{mOsm} / \mathrm{L})$ and isocaloric hyperosmolar $(>300 \mathrm{mOsm} / \mathrm{L})$ was decreased compared with isocaloric iso-osmolar solutions. A study by Marshall et al. (2005) reported that abomasal emptying rates following suckling of isotonic sodium acetate, $\mathrm{NaHCO}_{3}$, and $\mathrm{NaCl}$ solutions are similar, whereas the emptying rate of an all-milk-protein milk replacer containing $20 \%$ crude protein and $20 \%$ crude fat was significantly slower than the other solutions mentioned in the study. In a different study, calves fed a hypertonic OES $(717 \mathrm{mOsm} / \mathrm{L})$ demonstrated significantly slower emptying rates compared with calves fed a lower osmolality $(360 \mathrm{mOsm} / \mathrm{L})$ oral electrolyte 
(Nouri and Constable, 2006). The effect of osmolality on stomach motility has also been described in monogastric animals (Case et al., 1981; Kumar et al., 1987). Electrolyte solutions used for oral therapy of diarrhea are very useful if composed of suitable ingredients for the calves (Bachmann et al., 2009), but they can increase abomasal luminal pH (Smith et al., 2012) and decrease abomasal emptying if the osmolality reaches $600 \mathrm{mmol} / \mathrm{L}$ or higher (Smith and Berchtold, 2014). Either of these alterations may facilitate the colonization of the intestine with enteropathogenic bacteria (Smith, 2009). Overall, we can expect meals with higher caloric density and higher osmolality to empty more slowly from the abomasum as compared with meals with lower osmolality.

\section{Intra-abomasal Pressure}

Luminal pressure is known to have a significant effect on gastric emptying rate. For example, studies performed in dogs provided evidence of a linear association between increased luminal pressure and emptying rate (Strunz and Grossman, 1978). The authors concluded that contraction of the pyloric antrum and luminal pressure of the stomach affected gastric emptying. These findings have been confirmed in dogs (Keinke et al., 1984) and pigs (Anvari et al., 1995) in which studies further investigated the control of gastric motility based on feedstuff characteristics that regulated the flow of ingesta into the pylorus. In ruminants, the abomasal body (corpus abomasi) plays an important role in the emptying process (Cottrell and Stanley, 1992). Receptors measuring the pressure are mainly located at the pyloric antrum and the cranial part of duodenum (Phillipson, 1952; Cottrell and Reynolds, 1994), which affect emptying in both monogastrics and ruminants (Bell 1980a,b; Treacy et al., 1996).

Bell (1980a) carried out research on luminal pressure after drenching of $1.5 \mathrm{~L}$ of isotonic saline solution into the abomasum of calves. In the abomasum, no increase in pressure besides the contraction waves were seen (3.7 $\mathrm{mm} \mathrm{Hg}$ ). During contractions, pressure increased up to $14.7 \mathrm{~mm} \mathrm{Hg}$ in the pylorus and up to $7.4 \mathrm{~mm} \mathrm{Hg}$ in the body of the abomasum. These contractions were only partially synchronous with the electromyelographic recordings being done at the same time. More research is needed in calves to better define the role of intraluminal pressure on abomasal emptying and whether the volume of the ingested meal potentially affects pressure.

\section{Abomasal $\mathrm{pH}$}

The effect of abomasal $\mathrm{pH}$ on emptying rates is controversial. Bell and Watson (1976) claimed that gastric
$\mathrm{pH}$ values play an important role, but Ehrlein and Hill (1970) found only minor influence of $\mathrm{pH}$ on abomasal motility and emptying in calves. Luminal $\mathrm{pH}$ values higher than 10 and lower than 2 have been shown to inhibit abomasal emptying in calves (Bell et al., 1981b). Low abomasal $\mathrm{pH}$ is thought to be a risk factor leading to the development of abomasal ulcers (Constable et al., 2005), but an acidic environment also provides a barrier to prevent some bacteria from colonizing the intestinal tract. With increasing $\mathrm{pH}$ (above 5.0), the survival rate of potentially pathogenic bacteria such as Escherichia coli and Salmonella species increases and therefore colonization of small intestine and development of diarrhea in calves is more likely (Sen et al., 2006). Milk-fed calves exhibit a low luminal $\mathrm{pH}$ value in the preprandial period $(\mathrm{pH}<2.0)$, followed by a rapid increase to a luminal $\mathrm{pH}$ of 6 after suckling milk or milk replacer (Ahmed et al., 2002a,b). After a milk or milk replacer feeding, abomasal $\mathrm{pH}$ remains elevated for up to $2 \mathrm{~h}$ and then decreases to preprandial values within 7 to $9 \mathrm{~h}$ (Constable et al., 2005; Marshall et al., 2005). Similar results were reported in another study with an abomasal $\mathrm{pH}$ of 1.3 preprandial and 5.8 after a milk replacer feeding with a gradual return to preprandial values within $8 \mathrm{~h}$ (Smith et al., 2012). Another study evaluated the feeding frequency of milk replacer on abomasal pH in calves (Ahmed et al., 2002a). In calves fed milk replacer at $12 \%$ of their BW per day, the mean 24 -h abomasal $\mathrm{pH}$ was 3.44 in calves fed twice a day and slightly higher in calves fed 3 times (3.69), 4 times (3.64), or 8 times (3.67) per day. These studies used miniature glass $\mathrm{pH}$ electrodes that were inserted through abomasal cannulas to measure $\mathrm{pH}$. The administration of OES containing high bicarbonate concentrations resulted in a large increase in $\mathrm{pH}$ from 1.3 to 7.5 (mean 24-h pH 4.1 for solution without glycine and 3.5 for the solution with glycine). In contrast, an acetate-containing OES caused only a mild increase (mean 24-h pH 2.1), and luminal pH returned back to preprandial values by $3 \mathrm{~h}$ (Smith et al., 2012).

Calves fed an acidified milk replacer had an abomasal $\mathrm{pH}$ of $<4.0$ for a significantly greater percentage of the day compared with calves fed a nonacidified milk replacer (Woodford et al., 1987). However, it should be noted that calves in this study were fed milk replacer at $10 \%$ of their BW divided into 2 feedings while calves given acidified milk replacer were fed ad libitum. If $\mathrm{pH}$ $<4$ is recognized as a critical $\mathrm{pH}$ for preventing colonization of the intestine with potentially pathogenic bacteria such as E. coli or Salmonella species, then the abomasal $\mathrm{pH}$ of calves fed an acidified milk replacer stays closer to the desired range. However, this effect is most likely to be related to the high frequency of consuming of acidified replacer. 


\section{Dietary Protein}

Feeding saleable milk is not always cost effective; therefore, many modern dairy farms use milk replacers as a substitute. Skim milk, which is commonly used in Asian countries, and whey protein have often been the major protein component in milk replacers. For economic reasons, cheaper plant-derived proteins have also been used in milk replacers. Some studies have suggested that soy- and wheat-derived proteins might be suitable alternatives as calves reach an age of $4 \mathrm{wk}$ or greater (Montagne et al., 2001). Data on the effects of different proteins on abomasal emptying in calves are controversial, which might be linked to the different levels of intake and age of calves included in the various studies. Terui et al. (1996) and Ortigues-Marty et al. (2003) did not find any differences in abomasal emptying when investigating clinical, metabolic, and production parameters in calves fed either whey or milk replacers containing 30 to $50 \%$ of the crude protein from wheat gluten.

In contrast, another study described diarrhea and decreased feed intake and growth rates in calves fed milk replacers partially substituted $(52 \%)$ by a wheat gluten or potato plant protein, which are known to be have lower digestibility than whey protein or casein (Branco-Pardal et al., 1995). An experimental study on milk replacers made either partially (48\%) or totally from wheat protein was performed using abomasal and duodenal cannulas and showed an increase in abomasal emptying rate compared with skim milk or whey powder (Toullec and Formal, 1998). Similar results were seen when comparing $100 \%$ whey protein to whey and soy (50:50) or whey and fish (50:50) protein-based milk replacers, resulting in accelerated emptying rates seen with the milk replacers containing fish or soy (Gaudreau and Brisson, 1980). Caugant et al. (1994) did not find any differences in abomasal emptying in vivo between 3 milk replacers in which protein was provided by dried milk, partial (50\%) heated soybean flour, or partial (50\%) soy protein concentrate. Further studies on plant proteins, including hydrolyzed soy, soy concentrate, and potato concentrate, as partial (mixed 1:1 with skim milk) protein substitutes found shorter transit time through the jejunum, which was linked to the osmotic effects of undigested oligopeptides, amino acids, $\beta$-conglycinin, and glycine. The increased volume of undigested feed in the jejunum was likely the outcome of a combination of a decreased digestive enzyme capacity to digest proteins of plant origin and an increased abomasal emptying rate (Montagne et al., 2001). Calves fed milk replacers containing 7.7\% wheat protein showed a significantly faster abomasal emptying compared with calves fed milk replacer con- taining only milk protein; however, clinical parameters and weight gain did not differ between groups (Wittek et al., 2016). Another factor influencing the emptying time is the intake level of these mentioned ingredients, which did not affect the early studies with limited fed calves, but would be much higher with ad libitum fed calves. The different results between the various studies might be partially due to different processing methods of the milk- or plant-derived proteins, which may result in a wide variability of digestibility, solubility, and other properties of the proteins. Results might also vary depending on the inclusion rate of various alternative protein sources. Regardless, more data are needed on the suitability of non-milk protein sources for calves over 4 wk of age and their effect on abomasal emptying.

\section{Glucose, Insulin, and Milk Fat}

Increases in the concentration of peripheral insulin and glucose decreases electric activity and emptying rate of the abomasum in calves (McLeay and Bell, 1980). Subsequently, as a result of the reduction in glucose concentrations from insulin release, abomasal emptying rate is accelerated by a neural feedback mechanism, which has been seen in ruminating animals (van Meirhaeghe et al., 1988; Holtenius et al., 2000). Low glucose-containing OES given to calves provide faster rates of abomasal emptying compared with high glucose-containing OES (Nouri and Constable, 2006); however, high-glucose OES are most suitable for the treatment of hypoglycemic calves.

A minimal amount of information exists on how the fat content of milk or milk replacers effects abomasal emptying. In one study, a lard concentration varying from 5 to $25 \%$ in milk replacers did not have any significant effect on abomasal emptying in 4- to 6-wkold calves (Gaudreau and Brisson, 1980), contrary to reports in monogastric animals (Hunt and Knox, 1968). Milk replacers using corn oil as an unsaturated vegetable fat or butter oil or lard as saturated fats did not have any influence on abomasal emptying of 3- to 6 -wk-old calves. The authors concluded that the degree of unsaturation of dietary fats did not influence the abomasal emptying rate (Gaudreau and Brisson, 1978). Additionally, it has to be taken into consideration that changes in fat concentration may also result in changes of other parameters like lactose or mineral concentration and that combined effects may occur.

\section{METHODS FOR DETERMINATION OF ABOMASAL EMPTYING}

Abomasal emptying in calves has been evaluated using numerous methods. These include methods pri- 
marily limited to use in experimental settings, such as nuclear scintigraphy, as well as methods that could be used under field conditions. A variety of techniques exist for determining abomasal emptying, and they can be differentiated as direct or indirect or as invasive or noninvasive. Tests may also be for solid or fluid abomasal content.

\section{Direct Measurements to Determine Abomasal Emptying}

Direct invasive measurements have been developed for experimental, but not routine diagnostic use. Initially, cannulas were implanted in the abomasum and duodenum to evacuate the ingesta out of the abomasal body to measure volume, and these evacuation systems were later replaced by flowmeters (Ash, 1964; Sissons and Smith, 1978; Wanderley et al., 1985). In general, these early techniques have been highly criticized. One major criticism of this approach has been that the cannula penetrates the intestinal wall and thus likely damages the enteric nervous system affecting emptying (Ruckebusch and Kay, 1971; Komarek, 1981; Poncet and Ivan, 1984).

\section{Imaging Techniques to Measure Abomasal Emptying}

Radiologic examinations using contrast agents have been performed in calves and adult cattle to measure abomasal emptying (Mylrea, 1966; Nagel, 1965a,b). For example, Bell et al. (1977) used barium sulfate as a liquid radiopaque material in calves. This method is useful, but it has limitations and only provides qualitative results. Quantitative results (actually emptying rates) cannot be determined accurately using contrast media because of the constant flow rate from the abomasum to the intestine.

\section{Nuclear Scintigraphy}

Nuclear scintigraphy with technetium $99 \mathrm{~m}$ has long been the gold standard for measuring gastric emptying in humans (Maurer, 2012) and has been used for measuring abomasal emptying in milk-fed calves (Nappert and Lattimer, 2001; Marshall et al., 2005). Technetium $99 \mathrm{~m}$ has a short half-life, and because it emits radiation at different energies, both the solid and liquid phases of gastric emptying can be labelled. Although scintigraphy provides accurate data on abomasal emptying and should be considered the gold standard, it has several disadvantages. The cost and availability of a gamma camera and other expensive equipment is obviously a concern, and the use of nuclear material results in tissue residues. Therefore, these animals are never permit- ted to enter the food chain and have to be euthanized following the study. Because nuclear scintigraphy is not suitable for routine field studies, other methods have been developed and validated for use in calves.

\section{Ultrasonographic Measurement of Abomasal Dimensions}

Ultrasonographic measurement of the abomasal dimensions is an accurate method to calculate the abomasal volume and location in calves (Figure 1). Comparison of the abomasal volume before and after intake of a standardized meal permits an accurate determination of the abomasal emptying rate in calves (Wittek et al., 2005a). To perform ultrasonographic measurement of abomasal emptying rate in calves, the hair on the ventral aspect of the abdomen has to be clipped. A $3.5-\mathrm{MHz}$ ultrasound sector probe is applied to the ventral aspect of the abdomen in transverse and sagittal planes to determine the maximal ultrasonographically visible abomasal dimensions. Ultrasonographic measurements are performed immediately before the start of suckling and periodically after the start of suckling. Based on the assumption that the shape of the abomasum is ellipsoid, the equation for the volume of an ellipsoid can be used to calculate the volume of the abomasum (Wittek et al., 2005a). A modified power exponential equation can be used to calculate the half time of abomasal emptying from the abomasal volume using nonlinear regression. Abomasal curd formation can be seen and measured with ultrasound (Miyazaki et al., 2009). The use of ultrasound in examination of forestomachs in healthy calves and in ruminal drinker calves during their first $100 \mathrm{~d}$ of life was described by Braun and Gautschi (2013). Ultrasound was also used to determine the ruminal milk volume (milk that enters the rumen while the calf is suckling) by measuring the difference between total milk intake and abomasal milk volume after suckling (Labussière et al., 2014).

\section{Electromyography}

Electromyography records and analyzes differences in the electrical potentials in the stomach and intestinal wall to assume motility. The correlation between electrical signals and contraction of stomach muscular layers has not been interpreted consistently between studies (Ruckebusch and Brady, 1982; Pfaffenbach et al., 1998; Sanmiguel et al., 1998). Sissons (1983) examined preruminating calves to investigate the correlation between myoelectric activity and flow of the ingesta. He reported potential differences of 3.4 to 4.0 spikes/min in the abomasal wall, which was not influenced by the amount of milk consumed by the calves. These spikes 


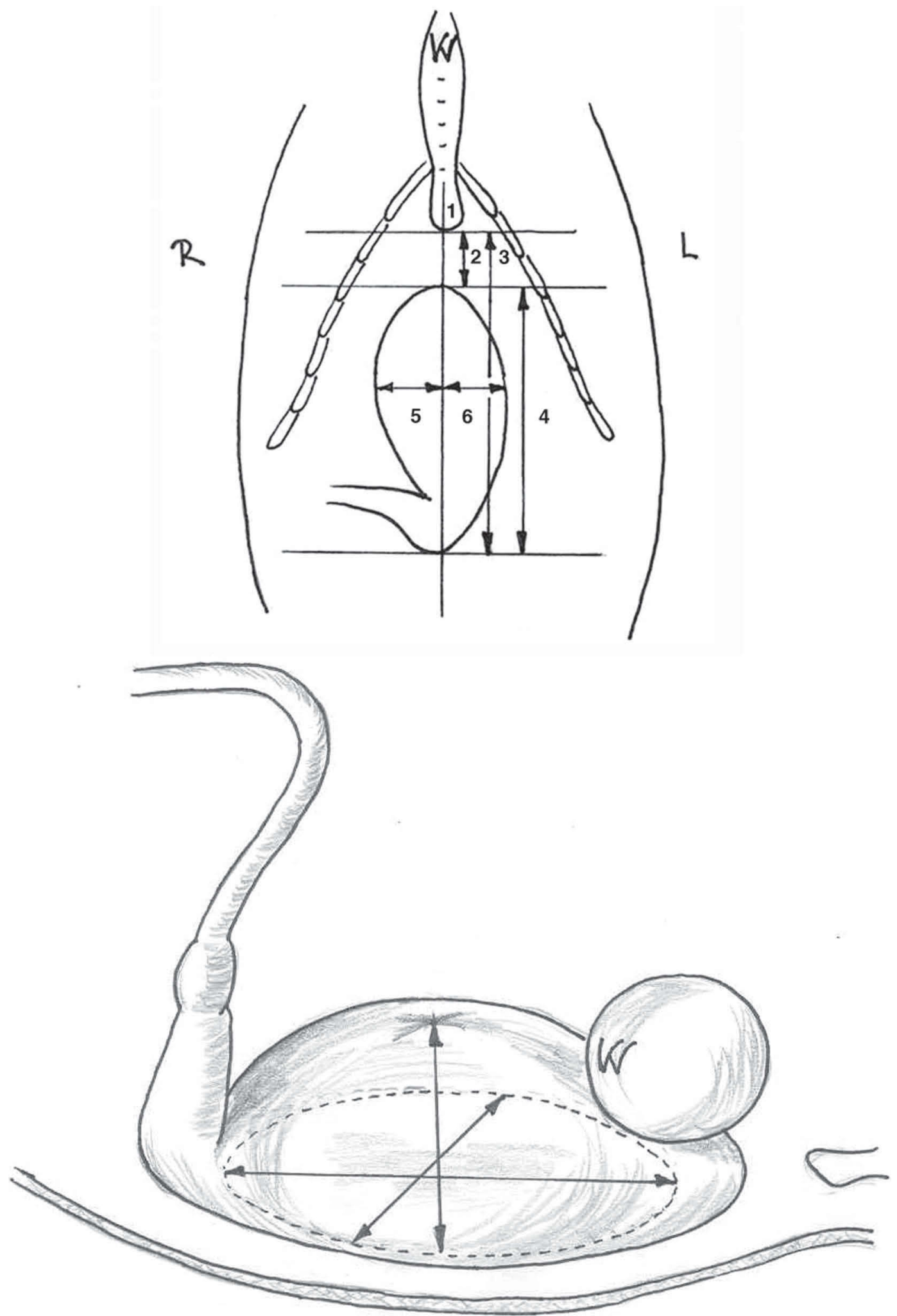

Figure 1. Illustrations of the measurement of abomasal surface projection in suckling calves. (Reprinted with permission from Am. J. Vet. Res.: Wittek et al., 2005a.) (A) Ventral view of the abdominal region of a calf. $\mathrm{R}$ and $\mathrm{L}=$ right and left sides of the calf; $1=$ xiphoid process; 2 $=$ cranial margin of the abomasum; $3=$ caudal margin of the abomasum; $4=$ length of the abomasum; $5=$ width of the abomasum to the right of midline of the abdomen; $6=$ width of the abomasum to the left of midline of the abdomen. (B) Right lateral view of the abdominal region of a calf with the head of the calf toward the right. 
were assumed to mix the ingesta in the abomasum, but not for their transport to the duodenum. However, the study also found that the myoelectric activity in the pyloric antrum was responsible for transport to the small intestine, which had previously been described by Bell and Grivel (1975).

\section{pH Monitoring}

This invasive technique of $\mathrm{pH}$ monitoring is performed using one or multiple surgically positioned cannulas in the abomasal body or the pyloric antrum. Monitoring of abomasal luminal $\mathrm{pH}$ in milk-fed calves can also give an estimate of the rate of emptying via measuring the time taken for luminal $\mathrm{pH}$ to return to within $1.0 \mathrm{pH}$ units of the preprandial value (Marshall et al., 2008). The increase in luminal $\mathrm{pH}$ results from the high $\mathrm{pH}$ of the liquid meals (relative to the normally acidic abomasal environment); therefore, the $\mathrm{pH}$ returns to preprandial values after the ingesta have been emptied from the stomach. This approach has been repeated by other authors (Ahmed et al., 2001, 2002a,b; Constable et al., 2005; Smith et al., 2012). Although it is not thought to predict abomasal emptying as accurately as ultrasonography or acetaminophen absorption (described in the following section), monitoring changes in abomasal $\mathrm{pH}$ after a meal provides a good estimate of abomasal emptying rate.

\section{Indirect Tests for Abomasal Emptying}

Indirect measurement of abomasal emptying implies that the technique does not directly attempt to measure how quickly or slowly ingesta empties from the abomasum, but instead measures something that is tightly controlled by the rate of emptying. Indirect measurement of the motility and emptying of the abomasum can be done by using resorption tests. These solutions, which are not absorbed in the abomasum but fully absorbed in the small intestine, are not metabolized; therefore, their concentration can be measured in blood. The use of acetaminophen and D-xylose has been described in both humans and animals (Heading et al., 1973; Maddern et al., 1985; Sanaka et al., 1997). Other resorption tests have been established for the measurement of gastric emptying in humans including C-octane acid, C-acetic acid, and the C-triolein breathing test (King et al., 1982; Braden et al., 1995; Choi et al., 1997). Some of these assays have been modified for testing absorption capacity of the intestine in calves with diarrhea (Holland et al., 1986).

Test solutions for resorption tests are water soluble; therefore, they can determine emptying of the fluid part of the ingesta accurately (Maddern et al., 1985), but not the solid phase. The abomasal content of cattle consists of 94 to $97 \%$ fluid, providing evidence that these absorption tests are reliable for measuring abomasal emptying (Faichney and Griffith, 1978; Malbert and Ruckebusch, 1988).

\section{Acetaminophen Absorption Pharmacokinetics}

Acetaminophen is commonly known as an analgesic and antipyretic drug in human medicine. It is absorbed in the small intestine after oral ingestion. The apparent rate of absorption of acetaminophen is much faster than the rate of elimination in suckling calves. The maximal acetaminophen concentration $\left(\mathbf{C}_{\max }\right)$ and time to maximal acetaminophen concentration $\left(\mathbf{T}_{\max }\right)$ after oral ingestion are primarily dependent on the rate of abomasal emptying. Acetaminophen absorption has been reported as a measure of abomasal emptying rate in suckling calves, with $\mathrm{T}_{\max }$ giving the most accurate indicator of emptying rate (Figure 2). Schaer et al. (2005) claimed that the ratio of $\mathrm{T}_{\max }$ to $\mathrm{C}_{\max }$ might be the best index in suckling calves. This claim was reviewed by using regression analysis, which indicated a linear relationship between to the 2 indices with a high $\mathrm{R}^{2}$ value $(0.88)$. However, the $\mathrm{R}^{2}$ value for $\mathrm{T}_{\max } /$ $\mathrm{C}_{\max }$ was lower than that for $\mathrm{T}_{\max }\left(\mathrm{R}^{2}=0.91\right)$, which remains the preferred method (Constable et al., 2006).

The procedure for acetaminophen absorption test has been described (Marshall et al., 2005). The substance $(50 \mathrm{mg} / \mathrm{kg}$ of $\mathrm{BW})$ is mixed in a carrier fluid (such as whole milk or milk replacer). Calves are generally allowed to suckle the milk to ensure closure of the esophageal groove. The drug is absorbed after being emptied from the abomasum and is distributed throughout the blood. Jugular (venous) blood is collected, and plasma acetaminophen concentrations are determined. Frequent sampling is important to ensure enough data points before and after the time of maximal acetaminophen concentration for performing nonlinear regression. Values for $\mathrm{C}_{\max }$ and $\mathrm{T}_{\max }$ are derived from the plasma acetaminophen concentration over time. To determine the precise emptying rate, the first derivative of a modified power exponential formula to model the acetaminophen concentration-time curve can be used (Constable et al., 2006). This approach is based on the fact that the acetaminophen concentration-time relationship, represented as a cumulative dose curve, is an inverse analog of the scintigraphic emptying curve. The first derivative of a modified power exponential model focuses on gastric emptying and subsequent small intestinal absorption of a marker substance and therefore provides a conceptually appropriate model for 


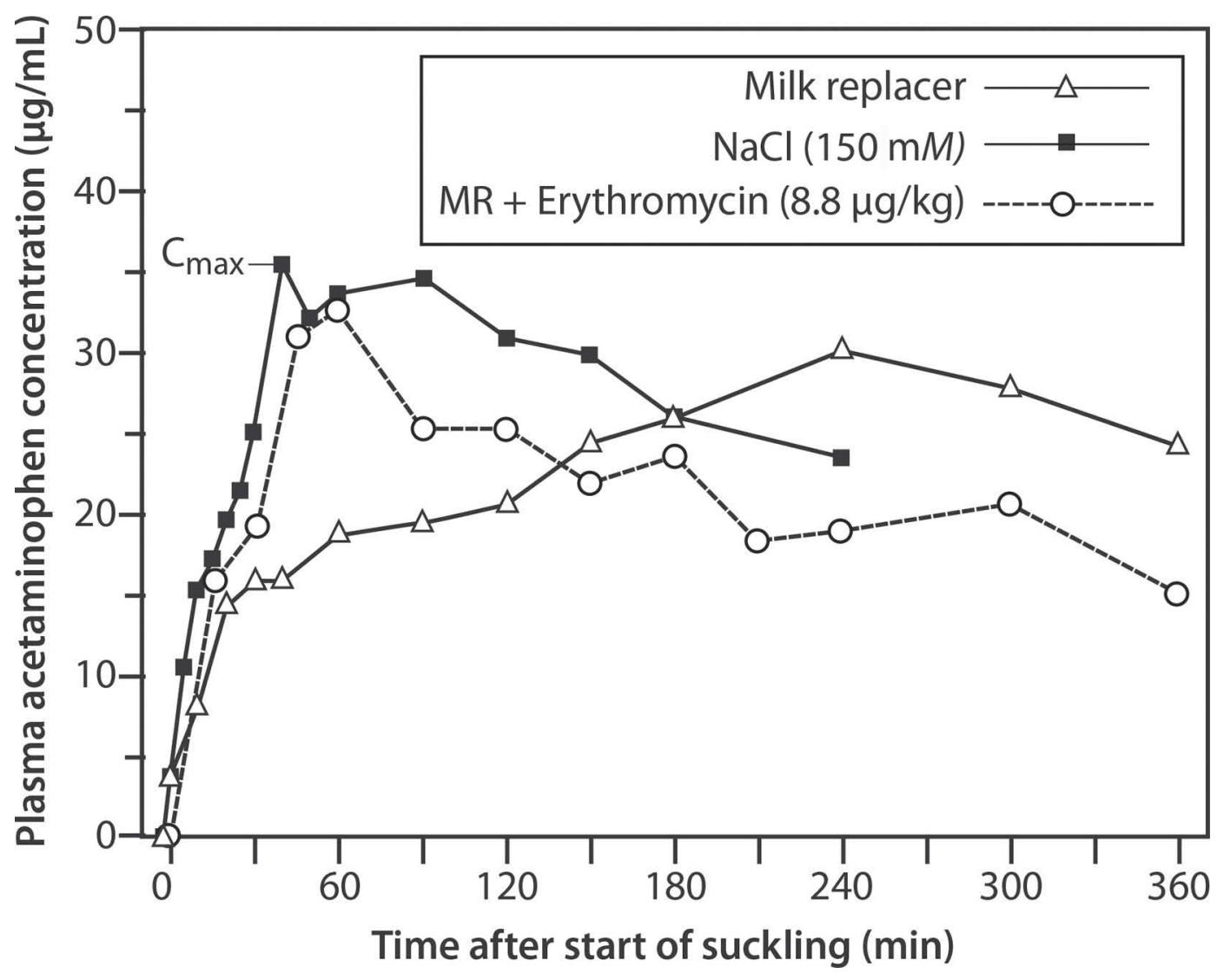

Figure 2. Mean plasma concentration of acetaminophen in calves after suckling a saline solution (150 $\mathrm{m} M \mathrm{NaCl})$ or milk replacer (MR) both with and without pretreatment with erythromycin. In each group, calves suckled $2 \mathrm{~L}$ of solution containing acetaminophen (50 mg/kg). One group of calves were given erythromycin $(8.8 \mathrm{mg} / \mathrm{kg}$, i.m.) $30 \mathrm{~min}$ before milk feeding. This figure demonstrates how to interpret an acetaminophen absorption pharmacokinetic profile as it relates to abomasal emptying. Both the maximum acetaminophen concentration $\left(\mathrm{C}_{\max }\right)$ and the time to reach maximal concentration $\left(\mathrm{T}_{\max }\right)$ are used to determine abomasal emptying. The faster the $\mathrm{T}_{\max }$, the faster the abomasal emptying. In this graph, we can see that the abomasum empties fastest after suckling $2 \mathrm{~L}$ of a $150 \mathrm{~m} M$ solution of $\mathrm{NaCl}$ ( $\mathrm{T}_{\max }$ about 35 min) compared with $2 \mathrm{~L}$ of $\mathrm{MR}\left(\mathrm{T}_{\max }\right.$ about $\left.4 \mathrm{~h}\right)$. Erythromycin is well known to be a prokinetic with profound effects on abomasal emptying as demonstrated here $\left(\mathrm{T}_{\max }\right.$ about $\left.55 \mathrm{~min}\right)$. Data for this figure were taken from Afshari et al. (2009) and Marshall et al. (2008).

assessing abomasal emptying rate. For comparison, the traditional one-compartment open model that is used to describe oral absorption pharmacokinetics simultaneously considers gastric emptying, small intestinal absorption, and systemic clearance, and it therefore provides a less precise estimate of abomasal emptying rate (Marshall et al., 2005).

Acetaminophen is water soluble and permits an estimate of the emptying rate of the liquid phase (such as milk or milk replacer), but not the solid or semisolid phase. The acetaminophen absorption test, a simple and accurate noninvasive method, is suitable for the assessment of abomasal emptying rate in field studies. It is a validated method that has produced very similar results to nuclear scintigraphy in calves (Marshall et al., 2005). However, in some countries it may not legally be possible to use acetaminophen in food-producing animals.

\section{D-Xylose Absorption Pharmacokinetics}

D-Xylose, a natural pentose sugar, may replace acetaminophen for measuring abomasal emptying rate. D-Xylose absorption is mainly influenced by abomasal emptying rate, although motility of the small intestine, the surface area available for absorption, and bacterial flora of the small intestine also influence the Dxylose concentration-time relationship. The D-xylose absorption test was first described as a diagnostic procedure for malabsorption syndrome in humans. Since that time, it has been used as a malabsorption test in adult cattle (Pearson and Baldwin, 1981) and calves (Seegraber and Morrill, 1979; Mir et al., 1993; Nappert et al., 1993). Wittek et al. (2005b) described a pharmacokinetic modeling approach to accurately estimate time to maximal D-xylose concentration as an index of abomasal emptying rate. D-Xylose absorption 
is maintained by active and passive transport mechanisms in the duodenum and proximal jejunum, but it is absorbed with low efficiency in cattle. Only 10 to $20 \%$ of orally administered D-xylose is absorbed in calves and lactating dairy cattle. The D-xylose test in suckling calves is performed by giving 0.5 to $1.3 \mathrm{~g}$ of $\mathrm{D}$-xylose per kilogram of BW as a 4.6 to $10 \%$ solution alone or as part of the fluid meal. The maximal plasma Dxylose concentrations were seen at $150 \mathrm{~min}$ in newborn to 6-wk-old dairy calves when D-xylose $(0.5 \mathrm{~g} / \mathrm{kg}$ of BW) was added to milk (Seegraber and Morrill, 1979), at 180 to $240 \mathrm{~min}$ in 8-d-old calves fed D-xylose (1.3 $\mathrm{g} / \mathrm{kg}$ of BW) in water as a $4.6 \%$ solution (Nappert et al., 1993), and at $90 \mathrm{~min}$ in 1- to 6 -wk-old calves fed D-xylose $(0.5 \mathrm{~g} / \mathrm{kg}$ of $\mathrm{BW})$ as a $10 \%$ solution (Mir et al., 1993).

\section{Dilution Tests}

Dilution tests using phenol red and polyethylene glycol have been used to measure abomasal emptying in several studies (George, 1968; Hunt, 1974; Beckers et al., 1988). Spectral photometric measurement of phenol red can only be done in clear fluids, which leads to problems in calves fed milk or milk replacer. The phenol red dilution method also assumes that abomasal secretion rates are identical for all test substances, which is not always correct when calves suckle different formulations of milk or milk replacer. This assumption also clearly becomes invalid with solutions that have different $\mathrm{pH}$ values, osmolality, and buffering capacity (Marshall et al., 2005). Chrome-EDTA, cobalt-EDTA, polyethylene glycol, ytterbium acetate, and ytterbium chloride are other marker substances that have been used for measuring abomasal emptying (Poncet and $\mathrm{Al}$ Abd, 1984; Van Bruchem et al., 1984; Siddons et al., 1985). The usage of polyethylene glycol was described by Breukink et al. (1988), when studying the failure of reticular groove reflex in nursing calves that led to persistent ruminal drinking. The same technique was described by Näslund et al. (2000) in an evaluation of different methods for measuring gastric emptying in humans.

\section{Other Testing Approaches}

Other diagnostic techniques, such as recording and analyzing the stomach and intestine sounds (Yuki et al., 2002), impedance scanning, computed tomography, and magnetic resonance imaging (McClelland and Sutton, 1985; Schwizer et al., 2002), are routinely used for evaluation of gastric motility examination in humans but have not been described in ruminants.

\section{POTENTIAL EFFECT OF ALTERATIONS IN ABOMASAL EMPTYING AND GASTROINTESTINAL DISEASE IN CALVES}

\section{Abomasal Bloat}

Several reports on a complex syndrome known as abomasal tympany, abomasal bloat, braxy-like disease, and abomasitis have been published (Roeder et al., 1987; Mills et al., 1990; Marshall, 2009). This syndrome in young calves is characterized by anorexia, abdominal distension, bloat, and often sudden death within 48 h (Panciera et al., 2007). In mild cases, clinical signs include diarrhea, watery fluid in the abomasum, and depression. Hyperglycemia (10.5-28 mmol/L) accompanied by glucosuria $(3-6 \mathrm{mmol} / \mathrm{L})$ may also be present. Severely affected calves show perceptible dehydration, colic, prominent abdominal distension, diarrhea, and recumbency. Systemic acidosis, as evidenced by low blood $\mathrm{pH}$, low serum bicarbonate concentration, and base deficit was reported by Roeder et al. (1987) for calves with abomasal bloat. Calves typically exhibit abdominal distension on the right side of the abdomen or potentially on both sides as the abomasum fills up with gas and occupies the majority of the abdominal cavity (Figure 3). At necropsy most of these calves present with abomasal tympany, forestomach and abomasal edema, hemorrhage, mucosal inflammation, erosion and necrosis, and occasionally mural emphysema. Emphysematous bullae are present in stomach walls of these calves (Glenn Songer and Miskimins, 2005).

Abomasal bloat most commonly occurs in dairy calves and seems to have a sporadic occurrence, with some farms having multiple outbreaks at times (Marshall, 2009). A survey of bovine practitioners reported that abomasal (acute) bloat syndrome is a common problem in dairy herds within the United States and has frequently been identified in well-managed herds (Midla et al., 2007). This survey further reported that a clear trend in the occurrence of abomasal bloat with regard to herd size, breed, or season is lacking. Abomasal bloat had been identified on farms using conventional milk replacers and milk replacers with higher protein and fat levels as well as on farms using both pasteurized and unpasteurized whole milk. No single diet type or feeding method emerged as a conspicuous risk factor for abomasal bloat in this survey. Other risk factors that have been reported for abomasal bloat include highosmolality milk replacers or OES, improper mixing of milk replacers, a large volume of milk being fed in a single daily feeding, cold milk (or milk replacer), water not being offered to calves, erratic feeding schedules, and failure of passive transfer (Marshall, 2009). 
A bacterial etiology is often mentioned in association with abomasal bloat. The most frequently incriminated bacterial pathogens includes Clostridium perfringens along with Campylobacter and Sarcina species (Eustis and Bergeland, 1981; Aubry, 2004; Glenn Songer and Miskimins, 2005). These pathogens have also been described as being associated with abomasal bloat in small ruminants (DeBey et al., 1996; Vatn et al., 2000). Additional bacterial pathogens isolated from calves affected with abomasal bloat include $\alpha$ streptococci, other streptococci species, and E. coli. Clostridium perfringens was most frequently seen as type $\mathrm{A}, \mathrm{E}$, or $\mathrm{C}$ producing $\beta$ toxin (Roeder et al., 1987). Beta toxin damages the intestinal microvilli, mitochondria, and terminal capillaries in the mucosa. Progressive necrosis of the mucosa follows and a large number of grampositive bacilli invade those areas. Clostridium perfringens type A was identified as the causative agent in a case report of 24 dairy calves dying from severe acute abomasal disease. The authors reported that the farm used antimicrobials inappropriately instead of establishing hygiene measures, and improvement was achieved by avoiding fecal contamination of the colostrum (Van Kruiningen et al., 2009). In another report, Sarcina-like bacteria were reported to contribute to the development of abomasal bloat in goat kids (DeBey et al., 1996). Histologic evidence of Sarcina species including Sarcina ventriculi and Sarcina maxima was detected in the superficial mucosa, but no bacteria could be cultured from the lesions (Edwards et al., 2008). Vatn et al. (2000) reported that evidence of Sarcina could be identified in the abomasal wall of all lambs with bloat; however, the bacteria could only be isolated in one case. In addition, investigators cultured Clostridium fallax and Clostridium sordellii out of the ingesta of lambs with abomasal bloat and failed to isolate these potential pathogens out of the ingesta of one healthy lamb (Vatn et al., 2000). Clostridium perfringens, E. coli, and Lactobacillus spp. were present in both case and control carcasses from that study. Intraruminal inoculations of $C$. perfringens type A into healthy dairy calves resulted in anorexia, depression, bloat, diarrhea, and death (Roeder et al., 1988).

Experimental induction of abomasal bloat in calves was achieved by drenching Holstein calves less than 10 $\mathrm{d}$ of age with a carbohydrate mixture containing milk replacer, corn starch, and glucose mixed in water to provide a meal with excessive fermentable carbohy-

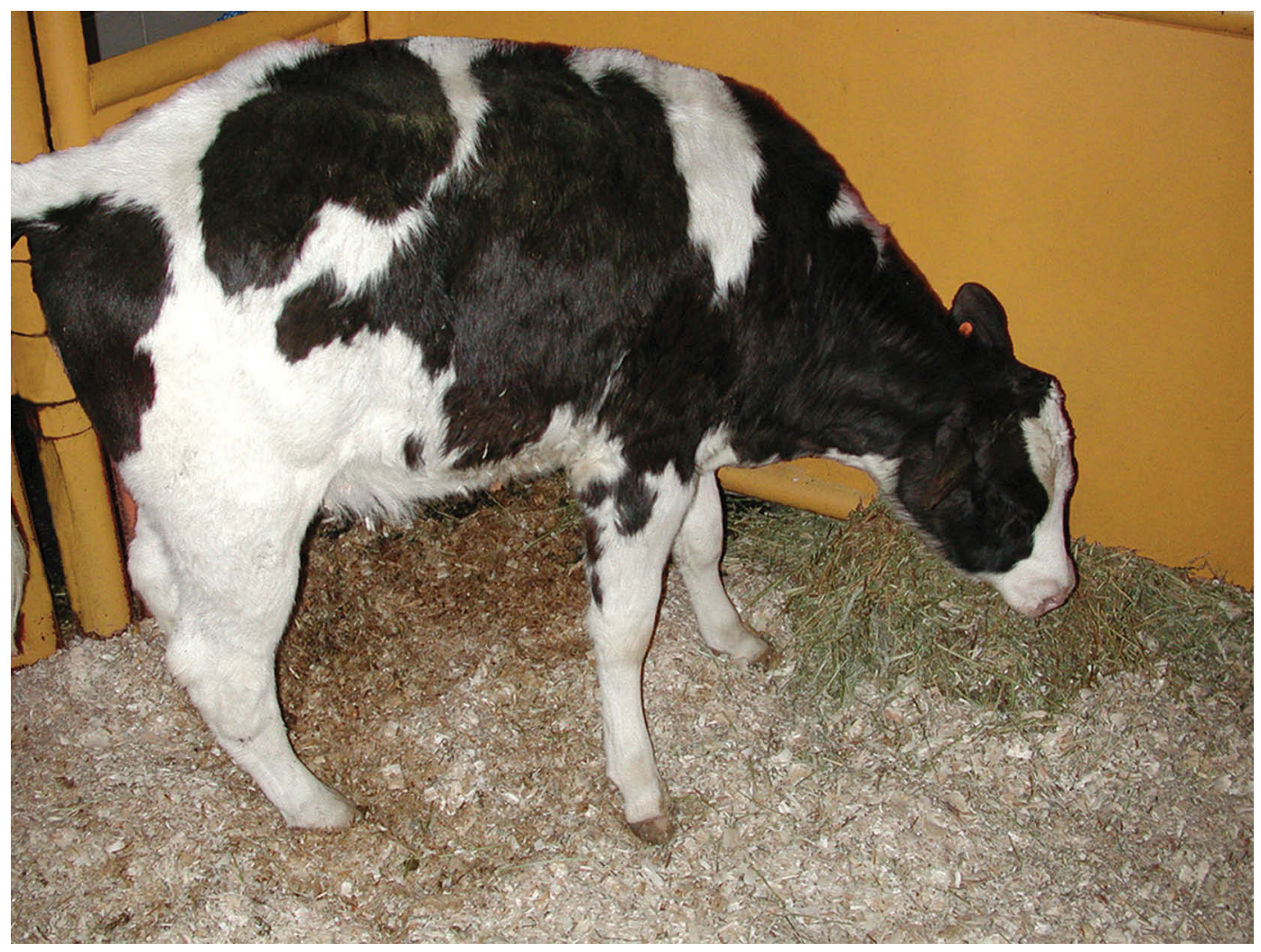

Figure 3. Holstein calf exhibiting clinical signs of abomasal bloat including depression and abdominal distension. Reprinted with permission from Marshall (2009). Color version available online. 
drate (Panciera et al., 2007). The authors suggested the syndrome of abomasal bloat in calves is multifactorial, and they proposed that the pathophysiology primarily involves excess fermentation of high-energy gastrointestinal contents in the abomasum (from milk, milk replacer, or high-energy OES), along with the presence of fermentative enzymes (produced by bacteria) leading to gas production and bloat. This process would be accelerated by anything that slowed abomasal emptying or caused gastrointestinal ileus. Ultimately, the exact etiology of abomasal bloat is unknown, but it likely involves both bacteria that produce gas as well as something that slows abomasal emptying. Control of abomasal bloat problems on a dairy farm generally begin with a thorough evaluation of the nutrition program to see if any changes need to be made. This evaluation would include what type of milk or milk replacer is being fed, volume fed at each feeding, feeding schedule, temperature of milk fed to calves, how the milk replacer is mixed, how feeding equipment is sanitized, and possibly even a water analysis in some cases. Recording the total solids of the milk replacer and potentially even measuring osmolality will provide additional information about the density and mixing consistency of the milk replacer being fed. A few studies have described the importance of proper feeding equipment sanitation. In one study, a chloride dioxide wash protocol was compared with one using sodium hypochlorite, but no differences were found on calf performance or health between the 2 protocols (Hill et al., 2015). The quality of drinking water and water used for reconstituting milk replacer is also important for calf health, and more research is needed in this area (Hird and Robinson, 1982). In addition, sanitation of milk feeding equipment is important for limiting bacterial growth. Anecdotally, focusing on controlling abomasal bloat through a nutritional approach is often much more successful than trying to control the problem by instituting $C$. perfringens vaccination. However, specific data on the efficacy of clostridial vaccines to control bloat have not been published.

Abomasal bloat should be differentiated from ruminal bloat, which occurs because of inadequate esophageal groove closure in young calves. The esophageal groove is a continuation of the lower esophagus, passing the medial wall of the reticulum and terminating in the reticulo-omasal orifice. The closure reflex is maintained by the suckling activity of the calf, and the groove is not properly closed if the calves drink out of buckets. It may also not close if milk temperatures are variable, the calves are under stress, calves are fed too low to the ground, or milk flow rates are too high (Blowey, 1994). Failure of esophageal groove closure leads to rumen drinking in which greater than normal amounts of milk enter the ruminoreticulum instead of the abomasum. Prolonged retention of milk in the rumen results in bacterial fermentation and production of lactic acid, leading to both a ruminal and systemic (metabolic) acidosis (Breukink et al., 1988). Clinical findings in ruminal drinker calves include refusal of milk, poor suckle reflex, recurrent ruminal bloat, and splashing sounds on the left side of the abdomen in young calves. Calves are frequently depressed and dehydrated, and they may die due to the severity of the metabolic acidosis. Treatment primarily involves rumen lavage with a stomach tube to siphon off the fermented milk remaining in the rumen along with fluid therapy to correct the acidosis. Although ruminal drinker syndrome has been described in calves representing multiple breeds, it appears to be most common in Simmental calves from Germany and Switzerland (Herrli-Gygi et al., 2008)

\section{Recent Changes in Dairy Calf Feeding}

Replacement heifer management is an expensive process (Heinrichs, 1993), and dairy producers often want early puberty, early breeding, and a young age at first calving (Lohakare et al., 2012) to shorten the time frame of an animal that is not economically profitable for the farm. The mammary gland of the heifer is also developing during the first year of life, and during the period from 3 to 9 mo of age, the growth rate of the mammary gland is faster than that of the rest of the body (Swanson and Poffenbarger, 1979). Preweaning average daily gain is positively correlated with first lactation milk yield. For example, one study showed that for every 1-kg increase in preweaning average daily gain, heifers produced $850 \mathrm{~kg}$ more milk in their first lactation and $235 \mathrm{~kg}$ more milk for every 1 Mcal of ME intake above maintenance (Soberon et al., 2012). Data similar to these findings have led to the realization that nutrition of the newborn dairy calf is a major factor influencing the ability of the growing animal to express her genetic capacity to produce milk. These findings are supported by a meta-analysis that reported calves with higher daily weight gains during the preweaning period show a significantly higher milk yield during the first lactation (Soberon and Van Amburgh, 2013).

Data also indicate that calves fed at a higher plane of nutrition are more resistant to disease than calves on more conventional milk feeding programs. In one study, pasteurized waste milk was shown to promote growth rates and decrease morbidity and mortality in calves in comparison with calves feed conventional milk replacer (Godden et al., 2005). In another study, calves fed a milk program designed for more preweaning growth (28\% protein, $20 \%$ fat) maintained hydration, had faster resolution of diarrhea, had increased BW gain, 
and showed better feed conversion after experimental challenge with Cryptosporidium parvum than calves fed conventional milk replacer (20\% protein, $20 \%$ fat; Ollivett et al., 2012). Although many people have long recognized that a strong correlation exists between calf nutrition and rates of disease, we have only recently had data to illustrate the importance of this relationship. With the plethora of new data published in the last 5 to $10 \mathrm{yr}$, it has been hard to avoid the realization that we have been significantly underfeeding dairy heifers for a long time and that more biologically relevant planes of nutrition provide multiple benefits (Khan et al., 2011).

To accomplish this goal, several new technologies have gained popularity, including novel milk replacers, automated calf feeding systems, and the acidification of milk fed ad libitum. In addition, many dairies have simply chosen to increase the volume of milk or milk replacer they feed to their calves. All of these have largely been introduced to assist dairy producers that wish to feed for more preweaning growth rates. Newer milk replacers providing increased nutrient density have been recommended by nutritionists to promote growth and development and attain the benefits associated with feeding calves at higher planes of nutrition (Davis Rincker et al., 2011). These milk replacers typically have a significantly higher osmolality than whole milk, which could potentially slow abomasal emptying. For example, raw bovine milk typically has an osmolality of approximately 275 to $285 \mathrm{mOsm} / \mathrm{L}$, whereas some newer milk replacers mixed according to label directions have osmolalities above $600 \mathrm{mOsm} / \mathrm{L}$. Modification of protocols to prepare milk replacers such as adding more powder than the directions would indicate or not mixing with the correct amount of water or using softened water would further increase osmolality and nutrient density. If water-soluble antimicrobials, coccidiostats, or other substances are added to the milk replacer, the osmolality increases even further and would slow abomasal emptying. Therefore, the concentration of protein and fat, the caloric density, and osmolality of milk or milk replacers fed to calves on dairy farms can vary significantly. In addition, the nutrient density of waste milk fed to calves can vary considerably, particularly on large dairy farms. For example, in one study, samples were collected from 12 different dairy farms representing milk that was being fed to calves (Moore et al., 2009). Percentages of total solids ranged from 5.1 to $13.5 \%$, and many samples were well below the 12.5 to $13 \%$ total solids value expected for whole milk. Therefore, it has become common for farms feeding whole milk to add additional powder (milk balancer) that is typically high in protein (approximately 25\%) and low in fat (about 10\%). Adding milk balancer to whole or pasteurized milk has been shown to increase growth rates in calves before weaning (Glosson et al., 2015).

Certainly, the benefits to feeding calves a higher plane of nutrition significantly outweigh the risks of potentially slowing abomasal emptying in the calf. By no means are we suggesting that higher protein milk replacers or pasteurized milk balancers are inappropriate; in fact, they have been used effectively on many dairy farms. However, we do believe that veterinarians, nutritionists, and producers should be aware of possible hazards with the use of very high osmolality milk or milk replacers or electrolyte products that could slow abomasal empting and facilitate bacterial fermentation in the abomasum (Nouri and Constable, 2006). Several feeding strategies can minimize the effect of more concentrated milk or milk replacer products on gastrointestinal health. For example, regularly estimating the nutrient density of milk by checking the percentage of total solids as it is being fed to calves helps prevent osmolality from getting extremely high and helps diagnose milk replacer mixing problems. Brix refractometers can be used and have been shown to provide a rapid and fairly accurate method for estimating milk total solids (Chigerwe and Hagey, 2014). Although exact recommendations for total solids are difficult to find in the published literature, in general abomasal bloat problems are often seen with total solid well above $15 \%$ (osmolality values over $650 \mathrm{mOsm} / \mathrm{L}$ ). Another strategy to limit the effect on abomasal emptying is to feed smaller volumes of milk more frequently. As farms feed large volumes (4 L or more) of concentrated milk or milk replacer meals in a single feeding, this exacerbates the negative effect on abomasal emptying. Feeding smaller volumes $(2-3 \mathrm{~L})$ multiple times per day has helped minimize the occurrence of bloat in some herds. This approach is often made more practical by the use of automated calf feeding systems. Maintaining regular feeding schedules and making sure milk or milk replacer is warm also anecdotally appear to help reduce the incidence of abomasal bloat, although the exact effect on abomasal emptying is unclear.

\section{Future Research Priorities and Conclusions}

Although much is known about factors that influence abomasal emptying, a lot remains to be learned about how to optimize abomasal emptying in modern calf feeding programs. Further studies on how different types and concentrations of milk replacer effect abomasal emptying are needed. This information will help answer the question of what total solid percentage 
is optimal for getting the most nutrition into a calf without risking gastrointestinal disease. Are 16 or $18 \%$ total solid milk or milk replacers safe if lower volumes are fed multiple times per day? For farms using automated calf feeders, what is the optimal volume to allow per feeding and how many times per day should calves be encouraged to suckle? For farms that feed large volumes of milk once a day, how is this affecting abomasal emptying? Additionally, the composition of milk replacers has been shown to possibly influence abomasal emptying. Further research seems to be necessary to assess the effects, especially of cheaper plant-derived proteins and fat. These proteins and fats are used and processed in various ways, which can make a difference in abomasal emptying. What are the effects of heat or cold stress on abomasal emptying, and do we need to change feeding recommendations during extreme weather conditions? Anecdotally, some veterinarians in northern climates have reported higher incidences of abomasal bloat during the winter. In contrast, the incidence in the southeastern United States is perceived to be higher during the summer when temperatures are above $32^{\circ} \mathrm{C}$. Although no real data are available on seasonality of abomasal bloat associated with different climates, nothing is known about the effects of heat or cold stress on abomasal emptying. With the popularity of acidified milk or milk replacers in some areas, a frequent question is how do they affect abomasal emptying. Although the effects of abomasal pH on emptying rates are controversial and not completely understood, as already discussed, it would be interesting to monitor the abomasal emptying rates of calves fed an acidified milk replacer and compare the results to those from calves fed an equivalent milk replacer that was not acidified. It would be good to have a better understanding of whether temperature of milk affects emptying and if cold milk replacer is truly emptied much slower. Another potential research topic would be the effect of other disease on gastrointestinal health. For example, one recent study found that calves with diarrhea had a delay in abomasal emptying when fed either milk or milk replacer with or without added OES in comparison with healthy calves (Kirchner et al., 2015). If abomasal emptying is already slower in calves with diarrhea, should feeding recommendations be altered in these animals? Further, it would be of interest to learn how different feeding regimens alter the bacterial community of the abomasum and small intestine. Overall, considerable work needs to be done to better understand the effects of different feeding programs on gastrointestinal health and how different milk replacers may affect abomasal emptying. This information will help optimize our ability to provide high planes of nutrition to calves, while minimizing the risk of disease.

\section{REFERENCES}

Adams, R. H. 1996. Physiologic, pathophysiologic and therapeutic implications for endogenous nitric oxide. J. Am. Vet. Med. Assoc. 209:1297-1302.

Abe, M., T. Iriki, K. Kondoh, and H. Shibui. 1979. Effects of nipple or bucket feeding of milk-substitute on rumen by-pass and on rate of passage in calves. Br. J. Nutr. 41:175-181.

Afshari, G.-R., M. Nouri, E. B. Hassan, M.-R. Mokhber-Dezfooli, and P. D. Constable. 2009. Effect of parenteral administration of ivermectin and erythromycin on abomasal emptying rate in suckling calves. Am. J. Vet. Res. 70:527-531.

Ahmed, A. F., P. D. Constable, and N. A. Misk. 2001. Effect of orally administered cimetidine and ranitidine on abomasal luminal $\mathrm{pH}$ in clinically normal milk-fed calves. Am. J. Vet. Res. 62:1531-1538.

Ahmed, A. F., P. D. Constable, and N. A. Misk. 2002a. Effect of feeding frequency and route of administration of abomasal luminal $\mathrm{pH}$ in dairy calves fed milk replacer. J. Dairy Sci. 85:1502-1508.

Ahmed, A. E., P. D. Constable, and N. A. Misk. 2002b. Effect of an orally administered antacid agent containing aluminium hydroxide and magnesium hydroxide on abomasal luminal $\mathrm{pH}$ in clinically normal milk-fed calves. J. Am. Vet. Med. Assoc. 220:74-79.

Anvari, M., J. Dent, and G. G. Jamieson. 1995. Mechanics of pulsatile transpyloric flow in the pig. J. Physiol. 488:193-202.

Appleby, M. C., D. M. Weary, and B. Chua. 2001. Performance and feeding behaviour of calves on ad libitum milk from artificial teats. Appl. Anim. Behav. Sci. 74:191-201.

Ash, R. W. 1964. Abomasal secretion and emptying in suckled calves. J. Physiol. 172:425-438.

Aubry, P. 2004. Abomasitis associated with Sarcina-like organisms in young dairy calves. Page 34 in Proc. 23rd World Buiatric Congress, Quebec, Canada. Canadian Association of Bovine Veterinarians, Saskatoon, Saskatchewan, Canada.

Bachmann, L., T. Homeier, S. Arlt, M. Brueckner, H. Rawel, C. Deiner, and H. Hartmann. 2009. Influence of different oral rehydration solutions on abomasal conditions and the acid-base status of suckling calves. J. Dairy Sci. 92:1649-1659.

Baker, J. S. 1979. Abomasal impaction and related obstructions of the forestomachs in cattle. J. Am. Vet. Med. Assoc. 175:1250-1253.

Beckers, E. J., N. J. Rehrer, F. Brouns, F. Ten Hoor, and W. H. M. Saris. 1988. Determination of total gastric volume, gastric secretion and residual meal using the double sampling technique of George. Gut 29:1725-1729.

Bell, F. R. 1980a. The mechanics controlling abomasal emptying and secretion. Pages 81-100 in Digestive physiology and metabolism in ruminant. Proc. 5th Int. Symp. Ruminant Physiology, ClermontFerrand, France. Springer Netherlands, Dordrecht, the Netherlands.

Bell, F. R. 1980b. The pressure relationship in the gastric body, antrum and duodenum during gastric emptying in the calf. Pages 485-493 in Digestive Physiology and Metabolism in Ruminant. Proc. 5th Int. Symp. Ruminant Physiology, Clermont-Ferrand, France. Springer Netherlands, Dordrecht, the Netherlands.

Bell, F. R., A. R. Green, J. A. H. Wass, and D. E. Webber. 1981a. Intestinal control of gastric function in the calf: The relationship of neural and endocrine factors. J. Physiol. 321:603-610.

Bell, F. R., and M. L. Grivel. 1975. The effect of duodenal infusion on the electromyogram of gastric muscle during activation and inhibition of gastric emptying. J. Physiol. 248:377-391.

Bell, F. R., S. E. Holbroke, and D. A. Titchen. 1977. A radiological study of gastric (abomasal) emptying in calves before and after vagotomy. J. Physiol. 272:481-493.

Bell, F. R., and L. M. McLeay. 1978. The effect of duodenal infusion of milk, casein, lactose, and fat on gastric emptying and acid secretion in the milk-fed calf. J. Physiol. 282:51-57.

Bell, F. R., M. Nouri, and D. E. Webber. 1981b. The interplay between hydrogen ions, bicarbonate ions and osmolarity in the anterior duodenum modulating gastric function in the conscious calf. J. Physiol. 314:331-341.

Bell, F. R., and S. A. D. Razig. 1973. Gastric emptying and secretion on the milk-fed calf. J. Physiol. 228:499-512. 
Bell, F. R., and D. J. Watson. 1976. The influence of gastric distension and duodenal infusate on the pattern of the stomach (abomasal) emptying in the pre-ruminant calf. J. Physiol. 259:445-456.

Bell, F. R., and D. E. Webber. 1979. A comparison of duodenal osmolality and energy content as controlling factors of gastric emptying in the calf. J. Physiol. 297:379-385.

Blowey, R. W. 1994. Calf feeding practices in relation to health. Cattle Pract. 2:76-79.

Braden, B., S. Adams, L. P. Duan, K. H. Orth, F. D. Maul, B. Lembcke, G. Hor, and W. F. Caspary. 1995. The ${ }^{13} \mathrm{C}$-acetate breath test accurately reflects gastric emptying of liquids in both liquid and semisolid test meals. Gastroenterology 108:1048-1055.

Branco-Pardal, P., J. P. Lalles, M. Formal, M. P. Cuiloteau, and R. Toullec. 1995. Digestion of wheat gluten and potato protein by preruminant calf: Digestibility, amino acids composition and immunoreactive proteins in ileal digesta. Reprod. Nutr. Dev. 35:639654 .

Braun, U., and A. Gautschi. 2013. Ultrasonographic examination of the forestomachs and the abomasum in ruminal drinker calves. Acta Vet. Scand. 55:1.

Breukink, H. J., T. Wensing, A. van Weeren-Keverling Buisman, E. G. van Bruinessen-Kapsenberg, and N. A. de Visser. 1988. Consequences of failure of the reticular groove reflex in veal calves fed milk replacer. Vet. Q. 10:126-135.

Case, G. L., L. D. Lewis, R. W. Phillips, and B. S. Cleek. 1981. Effect of osmolality of liquid nutrient diets of meal passage and nutrient absorption in Yucatan miniature swine. Am. J. Clin. Nutr. 34:1868-1878.

Caugant, I., H. V. Petit, M. Ivan, C. Bard, L. Savoie, R. Toullec, S. Thirouin, and M. Yvon. 1994. In vivo and in vitro gastric emptying of milk replacers containing soybean proteins. J. Dairy Sci. $77: 533-540$.

Chigerwe, M., and J. V. Hagey. 2014. Refractometer assessment of colostral and serum IgG and milk total solids concentrations in dairy cattle. BMC Vet. Res. 10:178.

Choi, M. G., M. Camilleri, D. D. Burton, A. R. Zinsmeister, L. A. Forstrom, and K. S. Nair. 1997. ${ }^{13} \mathrm{C}$ octanoic acid breath test to measure gastric emptying of solids: Accuracy, reproducibility and comparison with scintigraphy. Gastroenterology 112:1155-1162.

Constable, P. D., A. F. Ahmed, and N. A. Misk. 2005. Effect of suckling cow's milk or milk replacer on abomasal luminal $\mathrm{pH}$ in dairy calves. J. Vet. Intern. Med. 19:97-102.

Constable, P. D., W. Grünberg, and L. Carstensen. 2009. Comparative effects of two oral rehydration solutions on milk clotting, abomasal luminal $\mathrm{pH}$, and abomasal emptying rate in suckling calves. J. Dairy Sci. 92:296-312.

Constable, P. D., T. Wittek, A. F. Ahmed, T. S. Marshall, I. Sen, and M. Nouri. 2006. Abomasal $\mathrm{pH}$ and emptying rate in the calf and dairy cow and the effect of commonly administered therapeutic agents. Pages 54-68 in Proc. 24th World Buiatrics Congress, Nice, France. World Association for Buiatrics, Vienna, Austria.

Cottrell, D. F. 1994. Vagal reflex inhibition of motility in the abomasal body of sheep by antral and duodenal tension receptors. Vet. Res. Commun. 18:319-330.

Cottrell, D. F., and G. W. Reynolds. 1994. Electrophysical characteristics of tension receptors in the abomasal antrum of sheep. Vet. Res. Commun. 18:225-238.

Cottrell, D. F., and H. G. Stanley. 1992. An excitatory body-antral reflex in the sheep abomasum. Exp. Physiol. 77:565-574.

Davis Rincker, L. E., M. J. VandeHaar, C. A. Wolf, J. S. Liesman, L. T. Chapin, and M. S. Weber Nielsen. 2011. Effect of intensified feeding of heifer calves on growth, pubertal age, calving age, milk yield, and economics. J. Dairy Sci. 94:3554-3567.

DeBey, B. M., P. C. Blanchard, and P. T. Durfee. 1996. Abomasal bloat associated with sarcina-like bacteria in goat kids. J. Am. Vet. Med. Assoc. 209:1468-1469.

Dietz, O., E. Nagel, G. Prietz, R. Schenk, and V. Bergmann. 1970. Untersuchungen zur Vagusfunktion, zur Vagusbeeinflussung und zu Vagusausfällen am Verdauungsapparat des erwachsenen Rindes. Arch. Exp. Veterinarmed. 6:1385-1439.
Edwards, G. T., N. G. A. Woodger, A. M. Barlow, S. J. Bell, D. G. Harwood, A. Otter, and A. R. Wight. 2008. Sarcina-like bacteria associated with bloat in young lambs and calves. Vet. Rec. 163:391-393.

Ehrlein, H. J., and H. Hill. 1970. Einfluß des Labmagen- und Duodenalinhaltes auf die Motorik des Wiederkäuermagens. J. Vet. Med. A Physiol. Pathol. Clin. Med. 17:498-516.

Eustis, S. L., and M. E. Bergeland. 1981. Suppurative abomasitis associated with Clostridium septicum infection. J. Am. Vet. Med. Assoc. 178:732-734.

Faichney, G. J., and D. A. Griffith. 1978. Behaviour of solute and particle markers in the stomach of sheep given a concentrate diet. Br. J. Nutr. 40:71-82.

Gaudreau, J. M., and G. J. Brisson. 1978. Abomasum emptying in young dairy calves fed milk replacers containing animal or vegetable fats. J. Dairy Sci. 61:1435-1443.

Gaudreau, J. M., and G. J. Brisson. 1980. Abomasum emptying in dairy calves fed milk replacers with varying fat and sources of protein. J. Dairy Sci. 63:426-440.

George, J. D. 1968. New clinical method for measuring the rate of gastric emptying: The double sampling test meal. Gut 9:237-242.

Glenn Songer, J., and D. W. Miskimins. 2005. Clostridial abomasitis in calves: Case report and review of the literature. Anaerobe 11:290-294.

Glosson, K. M., B. A. Hopkins, S. P. Washburn, S. Davidson, G. Smith, T. Earleywine, and C. Ma. 2015. Effect of supplementing pasteurized milk balancer products to heat-treated whole milk on the growth and health of dairy calves. J. Dairy Sci. 98:1127-1135.

Godden, S. M., J. P. Fetrow, J. M. Feirtag, L. R. Green, and S. J. Wells. 2005. Economic analysis of feeding pasteurized nonsaleable milk versus conventional milk replacer to dairy calves. J. Am. Vet. Med. Assoc. 226:1547-1554

Gregory, P. C., S. J. Miller, and A. C. Brewer. 1985. The relation between food intake abomasal emptying and small intestinal transit time in sheep. Br. J. Nutr. 53:373-380.

Gregory, P. C., D. V. Rayner, and G. Wenham. 1984. Initiation of migrating myoelectric complex in sheep by duodenal acidification and hyperosmolarity: Role of vagus nerves. J. Physiol. 355:509-521.

Habel, R. E. 1956. A study of the innervation of the ruminant stomach. Cornell Vet. 46:555-633.

Heading, R. C., J. Nimmo, L. F. Prescott, and P. Tothill. 1973. The dependence of paracetamol absorption on the rate of gastric emptying. Br. J. Pharmacol. 47:415-421.

Heinrichs, A. J. 1993. Raising dairy replacements to meet the needs of the 21st century. J. Dairy Sci. 76:3179-3187.

Herrli-Gygi, M., A. Steiner, M. G. Doherr, J. W. Blum, M. Kirchhofer, and P. Zanolari. 2008. Digestive processes in ruminal drinkers characterized by means of the acetaminophen absorption test. Vet. J. 176:369-377.

Hill, T. M., X. Suarez-Mena, H. G. Bateman, J. M. Aldrich, and R. L. Schlotterbeck. 2015. Effect of feeding rate of milk replacer with early weaning and protocols for water treatment and sanitation on dairy calf growth and health. Prof. Anim. Sci. 31:375-382.

Hird, D. W., and R. A. Robinson. 1982. Dairy farm wells in southeastern Minnesota: The relation of water source to calf mortality rate. Prev. Vet. Med. 1:53-64.

Hoflund, S. 1940. Untersuchungen über Störungen in den Funktionen der Wiederkäuermagen, durch die Schädigungen des N. vagus verursacht. Svensk Veterinärtidskrift 45 Suppl. Isaac Marcus Boktryckeri-Aktiebolag, Stockholm, Sweden.

Holland, R. E., T. H. Herdt, and K. R. Refsal. 1986. Breath hydrogen concentration and small intestinal malabsorption in calves. Am. J. Vet. Res. 47:2020-2024.

Holtenius, K., K. Sternbauer, and P. Holtenius. 2000. The effect of plasma glucose level on the abomasal function in dairy cattle. J. Anim. Sci. 78:1930-1935.

Hopkins, B. A. 1997. Effects of the method of calf starter delivery and effects of weaning age on starter intake and growth of Holstein calves fed milk once daily. J. Dairy Sci. 80:2200-2203.

le Huërou-Luron, I., M. Gestin, G. Le Dréan, V. Romé, C. Bernard, J. A. Chayvialle, and P. Guilloteau. 1998. Source of dietary protein 
influences kinetics of plasma gut regulatory peptide concentration in response to feeding in preruminant calves. Comp. Biochem. Physiol. A Mol. Integr. Physiol. 119:817-824.

Hunt, J. N. 1974. A modification of the method of George for studying gastric emptying. Gut 15:812-813.

Hunt, J. N., and M. T. Knox. 1968. Regulation of gastric emptying. Page 1917 in Handbook of Physiology. C. F. Code and W. Heidel, ed. Am. Physiol. Soc., Washington, DC.

Hunt, J. N., and D. F. Stubbs. 1975. The volume and energy content of meals as determinants of gastric emptying. J. Physiol. 245:209225 .

Jahnberg, T., H. Abrahamson, G. Jansson, and J. Martinson. 1977. Vagal gastric relaxation in the dog. Scand. J. Gastroenterol. $12: 221-224$.

Jensen, M. B., L. R. Duve, and D. M. Weary. 2015. Pair housing and enhanced milk allowance increase play behavior and improve performance in dairy calves. J. Dairy Sci. 98:2568-2575.

Keinke, O., M. Schemann, and H. J. Ehrlein. 1984. Mechanical factors regulating gastric emptying of viscous nutrient meals in dogs. Q. J. Exp. Physiol. 69:781-795.

Kertz, A. F., and J. R. Loften. 2013. Review: A historical perspective of specific milk-replacer feeding programs in the United States and effects on eventual performance of Holstein dairy calves. Prof. Anim. Sci. 29:321-332.

Khan, M. A., D. M. Weary, and M. A. G. von Keyserlingk. 2011. Invited review: Effects of milk ration on solid feed intake, weaning, and performance in dairy heifers. J. Dairy Sci. 94:1071-1081.

King, C., L. Snook, P. Toskes, V. Brookeman, and E. Liberatori. 1982 Safety of ${ }^{14} \mathrm{CO}_{2}$-breath test: Dosimetry evaluation of ${ }^{14} \mathrm{C}$-triolein. Gastroenterology 82:1100. (Abstr.)

Kirchner, D., L. Schwedhelm, J. Wenge, I. Steinhöfel, C. Heinrich, M. Coenen, and L. Bachmann. 2015. Ultrasonographic imaging of abomasal milk clotting and abomasal diameter in healthy and diarrheic calves. Anim. Sci. J. 86:929-936.

Komarek, R. J. 1981. Intestinal cannulation of cattle and sheep with a T-shaped cannula designed for total digesta collection without externalizing digesta flow. J. Anim. Sci. 53:796-802.

Kuiper, R., and H. J. Breukink. 1988. Myoelectric patterns on the abomasal body in the adult cow recorded with stainless steel electrodes. Zentralbl. Veterinarmed. A 35:340-346.

Kumar, D., E. L. Ritman, and J. R. Malagelada. 1987. Three dimensional imaging of the stomach: Role of the pylorus in the emptying of liquids. Am. J. Physiol. 253:G79-G85.

Labussière, E., H. Berends, M. S. Gilbert, J. J. G. C. Van Den Borne, and W. J. J. Gerrits. 2014. Estimation of milk leakage into the rumen of milk-fed calves through an indirect and repeatable method. Animal 8:1643-1652.

Lohakare, J. D., K. H. Südekum, and A. K. Pattanaik. 2012. Nutrition-induced changes of growth from birth to first calving and its impact on mammary development and first-lactation milk yield in dairy heifers: A review. Asian-australas. J. Anim. Sci. 25:13381350 .

Low, A. G. 1990. Nutritional regulation of gastric secretion, digestion and emptying. Nutr. Res. Rev. 3:229-252.

Maddern, G., J. Miners, P. J. Collins, and G. G. Jamieson. 1985. Liquid gastric emptying assessed by direct and indirect techniques: Radionuclide labelled liquid emptying compared with simple paracetamol marker method. Aust. N. Z. J. Surg. 55:203-206.

Malbert, C. H., and C. Mathis. 1994. Antropyloric modulation of transpyloric flow of liquid in pigs. Gastroenterology 107:37-46.

Malbert, C. H., and Y. Ruckebusch. 1988. Gastroduodenal motor activity associated with gastric emptying rate in sheep. J. Physiol. 401:227-239

Malbert, C. H., and Y. Ruckebusch. 1991. Evacuation de la caillette chez les ruminants adults. Reprod. Nutr. Dev. 31:1-25.

Marshall, T. S. 2009. Abomasal ulceration and tympany of calves. Vet. Clin. North Am. Food Anim. Pract. 25:209-220.

Marshall, T. S., P. D. Constable, S. S. Crochik, and T. Wittek. 2005. Comparison of acetaminophen absorption and scintigraphy as methods for studying abomasal emptying rate in suckling dairy calves. Am. J. Vet. Res. 66:364-374.

Marshall, T. S., P. D. Constable, S. S. Crochik, T. Wittek, D. E. Freeman, and D. E. Morin. 2008. Effect of suckling an isotonic solution of sodium acetate, sodium bicarbonate, or sodium chloride on abomasal emptying rate and luminal $\mathrm{pH}$ in calves. Am. J. Vet. Res. 69:824-831.

Maurer, A. H. 2012. Advancing gastric emptying studies: Standardization and new parameters to assess gastric motility and function. Semin. Nucl. Med. 42:101-112.

McClelland, G. R., and A. J. Sutton. 1985. Epigastric impedance: A non-invasive method for assessment of gastric emptying and motility. Gut 26:607-614.

McLeay, L. M., and F. R. Bell. 1980. Effect of cholecystokinin, secretin, glucagon and insulin on gastric emptying and acid secretion in the calf. Am. J. Vet. Res. 41:1590-1594.

Meylan, M., T. M. Georgieva, M. Reist, J. W. Blum, J. Martig, I. P. Georgiev, and A. Steiner. 2004a. Distribution of mRNA that codes for subtypes of adrenergic receptors in the gastrointestinal tract of dairy cows. Am. J. Vet. Res. 65:1142-1150.

Meylan, M., T. M. Georgieva, M. Reist, J. W. Blum, J. Martig, I. P. Georgiev, and A. Steiner. 2004b. Distribution of mRNA that codes for 5-hydroxytryptamine receptor subtypes in the gastrointestinal tract. Am. J. Vet. Res. 65:1151-1158.

Midla, L. T., D. E. Shoemaker, and P. Rajala-Schultz. 2007. A survey of bovine practitioners to determine factors associated with acute bloat syndrome in pre-weaned dairy heifers. Pages 223-224 in Proc. 40th Annu. Conf., Vancouver, BC, Canada. Am. Assoc. Bovine Pract., Auburn, AL.

Miller-Cushon, E. K., R. Bergeron, K. E. Leslie, and T. J. DeVries. 2013. Effect of milk feeding level on development of feeding behavior in dairy calves. J. Dairy Sci. 96:551-564.

Mills, K. W., J. L. Johnson, R. L. Jensen, L. F. Woodard, and A. R. Doster. 1990. Laboratory findings associated with abomasal ulcers/tympany in range calves. J. Vet. Diagn. Invest. 2:208-212.

Mir, P. S., J. H. Burton, E. B. Burnside, and B. N. Wilkie. 1993. Effects of processing methods for soybean meal used in milk replacers on intestinal xylose uptake and serum antibody to soybean antigen when fed to calves of various ages. Can. J. Anim. Sci. 73:191-200.

Miyazaki, T., M. Miyazaki, J. Yasuda, and K. Okada. 2009. Ultrasonographic imaging of abomasal curd in preruminant calves. Vet. J. 179:109-116.

Montagne, L., R. Toullec, and J. P. Lallès. 2001. Intestinal digestion of dietary and endogenous proteins along the small intestine of calves fed soybean or potato. J. Anim. Sci. 79:2719-2730.

Moore, D. A., J. Taylor, M. L. Hartman, and W. M. Sischo. 2009. Quality assessments of waste milk at a calf ranch. J. Dairy Sci. 92:3503-3509.

Mylrea, P. J. 1966. Digestion in young calves fed whole milk ad lib and its relationship to calf scours. Res. Vet. Sci. 7:407-416.

Nagel, E. 1965a. Zur Problematik der Röntgenographie des Labmagens erwachsener Rinder. Erster Teil. Arch. Exp. Vet. Med. 20:609-654.

Nagel, E. 1965b. Zur Problematik der Röntgenographie des Labmagens erwachsener Rinder. Zweiter Teil. Arch. Exp. Vet. Med. 20:655-700.

Nappert, G., D. Hamilton, L. Petrie, and J. M. Naylor. 1993. Determination of lactose and xylose malabsorption in preruminant diarrheic calves. Can. J. Vet. Res. 57:152-158.

Nappert, G., and J. C. Lattimer. 2001. Comparison of abomasal emptying in neonatal calves with a nuclear scintigraphic procedure. Can. J. Vet. Res. 65:50-54.

Näslund, E., J. Bogefors, P. Grybäck, H. Jacobsson, and P. M. Hellström. 2000. Gastric emptying: Comparison of scintigraphic, polyethylene glycol dilution, and paracetamol tracer assessment techniques. Scand. J. Gastroenterol. 35:375-379.

Nouri, M., and P. D. Constable. 2006. Comparison of two oral electrolyte solutions and route of administration on the abomasal emptying rate of Holstein-Friesian calves. J. Vet. Intern. Med. 20:620-626. 
Nouri, M., and P. D. Constable. 2007. Effect of parenteral administration of erythromycin, tilmicosin, and tylosin on abomasal emptying rate in suckling calves. Am. J. Vet. Res. 68:1392-1398.

Nouri, M., M. R. Hajikolaee, P. D. Constable, and A. Omidi. 2008. Effect of erythromycin and gentamicin on abomasal emptying rate in suckling calves. J. Vet. Intern. Med. 22:196-201.

Okine, E. K., G. W. Mathison, M. Kaske, J. J. Kennelly, and R. J. Christopherson. 1998. Current understanding of the role of reticulum and reticulo-omasal orifice in the control of the digesta passage from the ruminoreticulum of sheep and cattle. Can. J. Anim. Sci. $78: 15-21$.

Ollivett, T. L., D. V. Nydam, T. C. Linden, D. D. Bowman, and M. E. Van Amburgh. 2012. Effect of nutritional plane on health and performance in dairy calves after experimental infection with Cryptosporidium parvum. J. Am. Vet. Med. Assoc. 241:1514-1520.

Olson, C., and S. Holmgreen. 2001. The control of gut motility. Comp. Biochem. Physiol. A 128:479-501.

Ortigues-Marty, I., J.-F. Hocquette, G. Bertrand, C. Martineau, M. Vermorel, and R. Toullec. 2003. The incorporation of solubilized wheat proteins in milk replacers for veal calves: Effects on growth performance and muscle oxidative capacity. Reprod. Nutr. Dev. 43:57-76.

Panciera, R. J., M. J. Boileau, and D. L. Step. 2007. Tympany, acidosis, and mural emphysema of the stomach in calves: Report of cases and experimental induction. J. Vet. Diagn. Invest. 19:392-395.

Pasricha, P. J., and H. P. Parkman. 2015. Gastroparesis: Definitions and diagnosis. Gastroenterol. Clin. North Am. 44:1-7.

Pearson, E. G., and B. H. Baldwin. 1981. D-Xylose absorption in the adult bovine. Cornell Vet. 71:288-296.

Pfaffenbach, B., R. J. Adamek, and G. Lux. 1998. The place of electrogastrography in the diagnosis of gastroenterological functions. Dtsch. Med. Wochenschr. 123:855-860.

Pfannkuche, H., D. Reiche, S. Hoppe, and M. Schemann. 2002. Cholinergic and noncholinergic innervation of the smooth muscle layers in the bovine abomasum. Anat. Rec. 267:70-77.

Phillipson, A. T. 1952. The passage of digesta from the abomasum of sheep. J. Physiol. 116:84-97.

Poncet, C., and A. Al Abd. 1984. Particulate and fluid passage studies in sheep fed a hay-based diet. Can. J. Anim. Sci. 64(Suppl.):77-79.

Poncet, C., and M. Ivan. 1984. Effect of duodenal cannulation in sheep on the pattern of gastroduodenal electrical activity and digestive flow. Reprod. Nutr. Dev. 24:887-902.

Radcliff, R. P., M. J. Vandehaar, L. T. Chapin, T. E. Pilbeam, D. K. Beede, E. P. Stanisiewski, and H. A. Tucker. 2000. Effects of diet and injection of bovine somatotropin on prepubertal growth and first-lactation milk yields of Holstein cows. J. Dairy Sci. 83:23-29.

Roeder, B. L., M. M. Chengappa, T. G. Nagaraja, T. B. Avery, and G. A. Kennedy. 1987. Isolation of Clostridium perfringens from neonatal calves with ruminal and abomasal tympany, abomasitis, and abomasal ulceration. J. Am. Vet. Med. Assoc. 190:1550-1555.

Roeder, B. L., M. M. Chengappa, T. G. Nagaraja, T. B. Avery, and G. A. Kennedy. 1988. Experimental induction of abdominal tympany, abomasitis, and abomasal ulceration by intraruminal inoculation of Clostridium perfringens type A in neonatal calves. Am. J. Vet. Res. 49:201-207.

Romański, K. W. 2002. Characteristics and cholinergic control of the "minute rhythm" in ovine antrum, small bowel and gallbladder. J. Vet. Med. A Physiol. Pathol. Clin. Med. 49:313-320.

Ruckebusch, Y., and C. J. Brady. 1982. Recording and analysis of electrical and mechanical activity of the gastrointestinal tract. Pages 1-28 in Techniques in Life Sciences. D. A. Titchen, ed. Elsevier Scientific Publishers Ireland Ltd., Shannon, Co. Clare.

Ruckebusch, Y., and R. N. B. Kay. 1971. Étude critique de la motricité gastrique chez les bovins. Ann. Rech. Vet. 2:99-136.

Ruckebusch, Y., and M. Pairet. 1984. Duodenal bulb motor activity in sheep. Zentralbl. Veterinarmed. A 31:401-413.

Sanaka, M., Y. Koike, T. Yamamoto, S. Mineshita, S. Yamaoka, S. Hirama, H. Tanaka, Y. Kuyama, and M. Yamanaka. 1997. A reliable and convenient parameter of the rate of paracetamol absorption to measure gastric emptying rate of liquids. Int. J. Clin. Pharmacol. Ther. 35:509-513.
Sanmiguel, C. P., M. P. Mintchev, and K. L. Bowes. 1998. Electrogastrography: A noninvasive technique to evaluate gastric electrical activity. Can. J. Gastroenterol. 12:423-430.

Schaer, S., M. Herrli-Gygi, N. Kosmeas, H. Boschung, and A. Steiner. 2005. Characteristics of acetaminophen absorption in healthy unweaned calves as an indirect measurement of the oroduodenal transit rate of liquid meals. J. Vet. Med. A Physiol. Pathol. Clin. Med. 52:325-332.

Schulze-Delrieu, K., and C. K. Brown. 1985. Emptying of saline meals by the cat stomach as a function of pyloric resistance. Am. J. Physiol. 249:G725-G732.

Schwizer, W., A. Steingötter, M. Fox, M. Thumshirn, P. Bösiger, and M. Fried. 2002. Non-invasive measurement of gastric accommodation in humans. Gut 51(Suppl. 1):i59-i62.

Seegraber, F. J., and J. L. Morrill. 1979. Effect of soy protein on intestinal absorptive ability of calves by the xylose absorption test. J. Dairy Sci. 62:972-977.

Sen, I., P. D. Constable, and T. S. Marshall. 2006. Effect of suckling isotonic or hypertonic solutions of sodium bicarbonate or glucose on abomasal emptying rate in calves. Am. J. Vet. Res. 67:13771384

Siddons, R. C., J. Paradine, D. E. Beever, and P. R. Cornell. 1985. Ytterbium acetate as a particulate-phase digesta-flow marker. Br. J. Nutr. 54:509-519.

Sissons, J. W. 1983. Effect of feed intake on digesta flow and myoelectric activity in the gastrointestinal tract of the preruminant calf J. Dairy Res. 50:387-395.

Sissons, J. W., and R. H. Smith. 1978. Measurement of flow and sampling of digesta in the preruminant calf. J. Physiol. 283:307-317.

Smith, G. W. 2009. Treatment of calf diarrhea: Oral fluid therapy. Vet. Clin. North Am. Food Anim. Pract. 25:55-72.

Smith, G. W., A. F. Ahmed, and P. D. Constable. 2012. Effect of orally administered electrolyte solution formulation on abomasal luminal $\mathrm{pH}$ and emptying rate in dairy calves. J. Am. Vet. Med. Assoc. 241:1075-1082.

Smith, G. W., and J. Berchtold. 2014. Fluid therapy in calves. Vet. Clin. North Am. Food Anim. Pract. 30:409-427.

Soberon, F., E. Raffrenato, R. W. Everett, and M. E. Van Amburgh. 2012. Preweaning milk replacer intake and effects on long-term productivity of dairy calves. J. Dairy Sci. 95:783-793.

Soberon, F., and M. E. Van Amburgh. 2013. The effect of nutrient intake from milk or milk replacer of preweaned dairy calves on lactation milk yield as adults: A meta-analysis of current data. J. Anim. Sci. 91:706-712.

Spring, C., M. Mevissen, M. Reist, M. Zulauf, and A. Steiner. 2003. Modification of spontaneous contractility of smooth muscles preparations from the bovine abomasal antrum by serotonin receptor agonists. J. Vet. Pharmacol. Ther. 26:377-385.

Strunz, U. T., and M. I. Grossman. 1978. Effect of intragastric pressure on gastric emptying and secretion. Am. J. Physiol. 235:E552E555.

Sun, W. M., S. Doran, K. L. Jones, E. Ooi, G. Boeckxstaens, G. S. Hebbard, T. Lingenfelser, J. E. Morley, J. Dent, and M. Horowitz. 1998. Effects of nitroglycerin on liquid gastric emptying and antropyloroduodenal motility. Am. J. Physiol. 275:G1173-G1178.

Swanson, E. W., and J. I. Poffenbarger. 1979. Mammary gland development of dairy heifers during their first gestation. J. Dairy Sci. 62:702-714.

Terui, H., J. L. Morrill, and J. J. Higgins. 1996. Evaluation of wheat gluten in milk replacers and calf starters. J. Dairy Sci. 79:12611266.

Thomas, J. E. 1957. Mechanics and regulation of gastric emptying. Physiol. Rev. 37:453-474.

Thomas, J. E., J. O. Crider, and J. J. Morgan. 1934. A study of reflexes involving the pyloric sphincter and antrum and their role in gastric evacuation. Am. J. Physiol. 108:638-700.

Toullec, R., and M. Formal. 1998. Digestion of wheat protein in the preruminant calf: Ileal digestibility and blood concentrations of nutrients. Anim. Feed Sci. Technol. 73:115-130. 
Treacy, P. J., G. G. Jamieson, and J. Dent. 1996. The effect of duodenal distension upon antro-pyloric motility and liquid gastric emptying in pigs. Aust. N. Z. J. Surg. 66:37-40.

Van Bruchem, J., T. van der Lende, J. G. de Swart, and G. A. Bangma. 1984. Abomasal emptying in sheep as related to the amount of protein entering the abomasum. Br. J. Nutr. 52:123-129.

Van Kruiningen, H. J., C. A. Nyaoke, I. F. Sidor, J. J. Fabis, L. S. Hinckley, and K. A. Lindell. 2009. Clostridial abomasal disease in Connecticut dairy calves. Can. Vet. J. 50:857-860.

van Meirhaeghe, H., P. Deprez, C. van den Hende, and E. Muylle. 1988. The influence of insulin on abomasal emptying in cattle. Zentralbl. Veterinarmed. A 35:213-220.

Vandeplassche, G., M. Claeys, W. Oyaert, and A. Houvenaghel. 1982a. Biotransformation of arachidonic acid by the antrum pyloricum of the bovine abomasum. Arch. Int. Pharmacodyn. Ther. 256:320323.

Vandeplassche, G., M. Claeys, W. Oyaert, and A. Houvenaghel. 1984. Influence of prostaglandins on bovine abomasum: Biosynthesis and in vitro motility experiments. Prostaglandins Leukot. Med. 14:15-24.

Vandeplassche, G., W. Oyaert, and A. Houvenaghel. 1982b. The influence of prostaglandins on in vitro motility of the fundus and the pyloric sphincter of the bovine abomasum. Arch. Int. Pharmacodyn. Ther. 260:306-308.

Vatn, S., M. A. Tranulis, and M. Hofshagen. 2000. Sarcina-like bacteria, clostridium fallax and clostridium sordellii in lambs with abomasal bloat, haemorrhage and ulcers. J. Comp. Pathol. 122:193200.

Vlaminck, K., C. van den Hende, W. Oyaert, and E. Muylle. 1984. Studies on abomasal emptying in cattle. II. Effect of infusions in duodenum and abomasum on electromyographic complexes, pressure changes and emptying of the abomasum. Zentralbl. Veterinarmed. A 31:676-682.

von Keyserlingk, M. A. G., F. Wolf, M. Hötzel, and D. M. Weary. 2006. Effects of continuous versus periodic milk availability on behavior and performance of dairy calves. J. Dairy Sci. 89:2126-2131.
Wanderley, R. C., C. Theurer, S. Rahnema, and T. H. Noon. 1985. Automated long-term total collection versus indicator method to estimate duodenal digesta flow in cattle. J. Anim. Sci. 61:1550-1558.

Wegrzyn, T. 1981. Motor activity of the abomasum in sheep. Acta. Physiol. Pol. 32:11-20

Wise, G. H., and J. P. Lamaster. 1968. Responses of calves to open-pail and nipple pail systems of milk feeding. J. Dairy Sci. 51:452-456.

Wittek, T., P. D. Constable, T. S. Marshall, and S. S. Crochik. 2005a. Ultrasonographic measurement of abomasal volume, location, and emptying rate in calves. Am. J. Vet. Res. 66:537-544.

Wittek, T., M. Ernstberger, M. Muckenhuber, and M. Flöck. 2016 Effects of wheat protein in milk replacers on abomasal emptying rate in calves. J. Anim. Physiol. Anim. Nutr. (Berl.) 100:264-270.

Wittek, T., K. Schreiber, M. Fürll, and P. D. Constable. 2005b. Use of the $\mathrm{D}$-xylose absorption test to measure abomasal emptying rate in healthy lactating Holstein-Friesian cows and in cows with left displaced abomasum or abomasal volvulus. J. Vet. Intern. Med. 19:905-913.

Woodford, S. T., H. D. Whetstone, M. R. Murphy, and C. L. Davis. 1987. Abomasal pH, nutrient digestibility, and growth of Holstein bull calves fed acidified milk replacer. J. Dairy Sci. 70:888-891.

Yasuda, K., K. Ono, N. Sasaki, T. Hayashi, S. Motoyoshi, A. Hasegawa, and I. Tomoda. 1988. Effect of concentrated feeding on plasma gastrin levels and abomasal acid secretion in an adult cow. Nihon Juigaku Zasshi 50:963-965.

Yuki, M., K. Adachi, H. Fujishiro, Y. Uchida, Y. Miyaoka, N. Yoshino, T. Yuki, M. Ono, and Y. Kinoshita. 2002. Is a computerized bowel sound auscultation system useful for the detection of increased bowel motility? Am. J. Gastroenterol. 97:1846-1848.

Zabielski, R., C. Dardillat, I. Le Huerou-Luron, C. Bernard, J. A. Chayvialle, and P. Guilloteau. 1998. Periodic fluctuations of gut regulatory peptides in phase with the duodenal migrating myoelectric complex in preruminant calves: Effect of different sources of dietary protein. Br. J. Nutr. 79:287-296. 